\title{
Title: Updated Perspectives on Vascular Cell Specification and Pluripotent Stem Cell-derived Vascular Organoids for Studying Vasculopathies
}

\author{
Chenxin Liu\#, Kaiyuan Niu\#, and Qingzhong Xiao* \\ Centre for Clinical Pharmacology, William Harvey Research Institute, Barts \\ and The London School of Medicine and Dentistry, Queen Mary University of \\ London, London EC1M 6BQ, UK
}

\#C Liu and K Niu contributed equally to this study

Running title: PSC-derived Vascular Organoids

${ }^{*}$ Correspondence to:

Dr QingzhongXiao (q.xiao@qmul.ac.uk), Heart Centre, William Harvey Research Institute, Barts and The London School of Medicine and Dentistry, Queen Mary University of London, Heart Centre, Charterhouse Square, London EC1M 6BQ, United Kingdom. Tel: +44(0)2078826584. 


\begin{abstract}
Vasculopathy is a pathological process occurring in the blood vessel wall, which could affect the haemostasis and physiological functions of all the vital tissues/organs and is one of the main underlying causes for a variety of human diseases including cardiovascular diseases. Current pharmacological interventions aiming to either delay or stop progression of vasculopathies are suboptimal, thus searching novel, targeted, risk-reducing therapeutic agents, or vascular grafts with full regenerative potential for patients with vascular abnormalities are urgently needed. Since first reported, pluripotent stem cells (PSCs), particularly human induced pluripotent stem cells, have open new avenue in all research disciplines including cardiovascular regenerative medicine and disease remodelling. Assisting with recent technological breakthroughs in tissue engineering, in vitro construction of tissue organoid made a tremendous stride in the past decade. In this review, we provide an update of the main signal pathways involved in vascular cell differentiation from human PSCs and an extensive overview of PSC-derived tissue organoids, highlighting the most recent discoveries in the field of blood vessel organoids as well as vascularization of other complex tissue organoids, with the aim of discussing the key cellular and molecular players in generating vascular organoids.
\end{abstract}

\title{
Key Words:
}

Vascular organoid; Organoid vascularization; Tissue-engineered vascular graft; Vasculopathy; Vascular disease; Pluripotent stem cell; Induced pluripotent stem cell; Embryonic stem cell; Blood vessel; Vascular endothelial cell; Vascular smooth muscle cell. 


\section{Introduction}

Vasculopathy is an umbrella term used to summarize a plethora of vascular diseases characterized by abnormalities of the vasculatures. These pathological anomalies are often associated with a variety of risk factors or as a direct result of pre-existing conditions including diabetes, rheumatic diseases, livedoid vasculopathy, and systemic sclerosis. Vasculopathy is the key underlying cause of cardiovascular disease (CVD), which is the prevailing cause of mortality in modern society, accountable for more than $36 \%$ of all deaths worldwide ${ }^{1}$. Current mainstream pharmacological interventions aim to either delay or stop progression of vasculopathies and subsequent high-risk cardiovascular events ${ }^{2}$. Despite extensive clinical usage and compelling results from both pre-clinical and clinical studies, a gap of knowledge yet remains with regard to the precise mechanisms of most therapeutic interventions, not to mention the risk profile associated with long-term exposure of various preventative drug therapies, complexed by a myriad of patient-to-patient inconsistencies that might inevitably lead to contradicting treatment outcomes ${ }^{3}$. Thus, the introduction of novel, targeted, risk-reducing therapeutic agents for patients with vascular abnormalities pose a considerable challenge for the advancement of vascular disease prevention, treatment and healthcare.

Over the past decades, the world had come to appreciate the power of modern technologies which had enabled advancements in uncovering the biochemical bedrocks of vascular diseases. The revelation that specific biological signalling pathways facilitating pathophysiological events had driven extensive mechanistic studies toward targeted treatments and drug development. For instance, endothelial dysfunction, inflammation and lipid infiltration were initially believed to be the precursors of atherosclerotic lesions ${ }^{4}$, however, the scope of the problem was greatly underestimated as countless follow-up studies revealed an elaborate, interwoven network of communications between different cell types, signalling molecules and downstream effectors ${ }^{5}$, with many still under debate for their validities. Moreover, identification of novel biomarkers for diagnostics and targeted therapies is an arduous process that also demands tremendous efforts from the current experimental models, which unfortunately has become somewhat obsolete in many aspects.

Traditionally, scientists have relied on in vitro systems to conduct mechanistic studies at a cellular/tissue level. The simplistic, cost-effective nature of in vitro setups had become well-integrated by most fields of biochemical research, yet many do agree unanimously to the rhetoric that primary or immortalised cells differ tremendously from their tissue-level counterparts, therefore do not reflect normal cellular behaviours in their naïve microenvironments ${ }^{6}$. In vivo and ex vivo animal models are considered the other 'pillar' of vascular research, which 
enabled researchers to recreate key pathophysiological events whilst assessing multiple influencers at once, and most importantly, to observe systemic changes within a live organism. However, most animal models suffer from poor translatability because of the intrinsic differences in physiological characteristics between human and other organisms, which have led to inconsistencies that are detrimental for translating pre-clinical findings into meaningful clinical outcomes ${ }^{7}$. Consequently, to guarantee reproducibility and translatability in vascular research, more innovative, reflective and sophisticated modelling techniques are required to overhaul current established systems.

The first human pluripotent stem cell (hPSC) line, more specifically human embryonic stem cell (hESC), was prominently introduced in $1998^{8}$. Due to its huge potential to self-renew indefinitely and differentiate into any desirable cell type under controlled laboratory settings, hESC has been highly applicable in many research disciplines. Although this potential was realized shortly after, many researchers avert their eyes due to concerns over ethical issues, immune rejection, availability and patient-specificity. However, with the emergence of human induced pluripotent stem cell (hiPSC) technology ${ }^{9}$, it is now possible to obtain an unlimited source of patient-specific hiPSCs devoid of any ethical and immunological concerns. Once established, hiPSC lines encompass all the essential characteristics of human hESCs without the need to sabotage human blastocysts, while remaining autologous and disease-specific to its patientorigin; moreover, introduction of powerful gene-editing tools such as Zinc Finger Nuclease (ZFN), transcription activator-like effector nucleases (TALEN) and CRISPR-CAS9, together with hiPSC technology, brings new insights to the pathophysiological roles of disease-related genes, and facilitates discoverydriven, high-throughput drug screening without the concerns for cell availability. Joining forces with recent technological breakthroughs in the field of tissue engineering, in vitro construction of tissue mimetic via a combination of scaffold materials, key growth factors and hPSCs ${ }^{10}$, breathed new life into an otherwise stagnant monolayer culture system that was widely adopted in most early stem cell research. By virtue of incorporating critical biophysical cues such as dimensionality, stiffness and tomography ${ }^{11}$, three-dimensional (3D) culture systems far outclass traditional 2D systems in translatability and scalability, as many have found success from small-scale tissue reconstruction, including skeletal muscle fibres ${ }^{12}$, vascular grafts ${ }^{13}$, cartilage tissues ${ }^{14}$ and Organ-On-AChip ${ }^{15}$, to large-scale reconstruction of organs with de-cellularized extracellular matrix (ECM) scaffold and hPSCs ${ }^{16}$. In this Review we will seek to examine the more recent discoveries in hPSC-derived vascular cells and blood vessel organoids, with particular emphasis on the newly reported key signalling pathways governing vascular cell specification and most recently established protocols in generating vascular organoids and the vascularization of other 
complex tissue organoids.

\section{Vascular cell specification and tissue engineering}

Vascular mural cells (MCs) and endothelial cells (VECs) are the two main functional cell types within human blood vessels (Figure 1). MCs can be further categorized into vascular smooth muscle cells (VSMCs) and pericytes. VSMCs are predominantly located in the middle layer of most arterioles and all arteries, whereas pericytes are most frequently found to reside along abluminal side of VECs that line the luminal surface. The phenotypic and functional identities of these vascular cells are pre-determined and are guided by spatiotemporal activation of particular signalling pathways at early embryonic development ${ }^{17-}$ 20.

\subsection{Vascular cell differentiation from human PSCs}

Based on key discoveries in embryonic vascular development, three wellaccepted methods have been established for the generation of vascular cells from hiPSCs (Figure 2): 1) hiPSCs were first differentiated into neural crest stem cells (NCSCs) by fibroblast growth factor 2 (FGF-2) treatment ${ }^{21,22}$, then matured into VSMCs by seeding the NCSCs onto a relative stiff matrix, which were maintained in serum-free media containing transforming growth factor- $\beta 1$ (TGF- $\beta 1$ ), as a result, the matured VSMCs exhibited enhanced mechanical properties $^{23}$; 2) hiPSCs were differentiated into mesoderm following the treatment of bone morphogenic protein 4 (BMP4) and GSK3 inhibitors CHIR99021/CP21, the mesoderm was then treated with vascular endothelial growth factor (VEGF) and Forskolin to induce VECs specification; alternatively, by using platelet-derived growth factor-BB (PDGF-BB) and Activin-A to induce VSMC specification ${ }^{24}$. As a result, the induced VECs and VSMCs were comparable to primary cells in transcriptomes, metabolomic profiles and functional properties, as well as drastically reduced differentiation period in contrast to previous study ${ }^{25}$; 3 ) instead of traditional static culture set up, the introduction of dynamic forces, such as shear stress, combined with VEGF and FGF treatments, can accelerate VEC specification and yield a greater number of tube-like network; in particular, the improved maturation of VECs was accompanied by upregulated Notch1 signalling and F-Actin filament reaglinment by media flow ${ }^{26}$. It is worth noting that the response of iPSC-induced VECs to shear stress was different from human umbilical artery/vein endothelial cells, as distinguished by specific marker gene expressions ${ }^{27}$; overall, external mechanical stimuli can help facilitate the maturation of iPSC-derived VECs.

Regarding the protocols mentioned above, despite all three approaches 
sharing several intrinsic similarities in culture methods, there are fundamental differences which could be reflected in the time of establishment, phenotypic/functional differences in matured vascular cells and their potentials in clinical applications. In terms of timeline, protocol 1 was reported in 2015, followed by protocol 2 in 2019, and protocol 3 in 2020. The establishment of later protocols was somewhat inspired by the previously established protocols, for example in protocol 2, VSMCs and VECs were efficiently and rapidly induced using monolayer-directed differentiation method that is more time- and cost-efficient, whilst being accessible for most laboratories ${ }^{28}$ comparing to embryoid body (EB) formation; however, since the induced vascular cells were generated in static media in vitro, meaning a lack in any forms of biophysical stimulations, which is an important functional parameter for real blood vessels. In addition, there was no distinction between arterial and venous VECs in protocol 2, where the induced cells were far less capable in mechanical durability and therefore unsuitable for clinical usage. To circumvent this drawback, protocol 3 incorporated distinctive magnitudes of shear stress in addition to in vitro culture setup, correspondingly, it was found that shear stress also played an important role in specification of mouse iPSCs towards venous or arterial ECs, as evidenced by upregulated marker expressions for general VECs and arterial ECs, elevated level of nitric oxide secretion and parallel alignment of VECs to the direction of the laminar flow ${ }^{26}$. Nevertheless, protocol 3 was predominantly an in vitro differentiation strategy, where iPSCs are of mouse origin and the induction of VSMCs was not included; whereas protocol 1 encompassed both cyclic circumferential stretching and in vivo biological environment as two co-existing factors to induce VSMCs from human iPSCs. The induced VSMCs exhibited enhanced mechanical strength and more durable vascular grafts ${ }^{23}$. As for the growth factor combinations deployed for each protocol, there are no studies confirming which combination is the most optimal. Importantly, it is worth mentioning that these vascular cells generated from PSCs in these three protocols were still fraught with numerous intrinsic limitations including cell-to-cell and line-to-line heterogeneity, as well as functional, metabolic and biological immaturity of these hPSC-derived cells. Therefore, these protocols are still confined in generating differentiated vascular cells, albeit with adequate morphologies and acceptable functional capacity, are not ready for generating in vivo self-assembling vessels or creating in vitro engineered vascular grafts yet. In conclusion, more research has yet to be done before the wide-spread adoption of cell-based therapeutic strategies can take place in clinical application.

\subsection{Signalling pathways in vascular cell specification}


Naturally, the transition from PSCs into VSMCs and VECs encompasses many signalling pathways that facilitate stem or progenitor cells to commit into a specific lineage, and ultimately mature into vascular cells. Knowledge of these underlying signalling mechanisms is therefore crucial for designing in vitro induction protocols, whether to construct tissue-engineered vascular graft (TEVG) or blood vessel organoid (see later section). In this section, we mainly focus on the most recent updates on two vital signalling pathway, Notch and Wnt (Table 1) and their involvements in vascular differentiation, whereas others such as TGF- $\beta 1$, PDGF-BB, serum response factor, retinoic acid, small GTPase RhoA, reactive oxygen species ${ }^{29-31}$, VEGF, TGF- $\beta /$ BMPs $^{32}{ }^{33}$, histone deacetylases ${ }^{34-37}$, micro-RNAs $s^{38-40}$, matrix metalloproteinase ${ }^{41-43}$, and extracellular matrix-integrin signalling ${ }^{44}$, will not receive many attentions as they have already been elucidated comprehensively in previous reviews ${ }^{45-53}$.

\subsubsection{Canonical Notch signalling pathway}

Canonical Notch is a highly conserved signalling pathway that plays a crucial role in MC and VEC specification ${ }^{54}$, as evidenced by disruption of Notch signalling can lead to failure in arterial lineage commitment, malformation of vascular network and even embryonic lethality ${ }^{20}$. Notch 3 is most predominantly expressed in MCs, where a loss of function mutation in mouse embryonic cells can result in stepwise disruptions of arterial VSMCs ${ }^{55-57}$. Additionally, it was shown in zebrafish that Notch3 upregulates MC proliferation, and activation of different Notchs, such as Notch2 and Notch3, in the mesenchyme precedes MC specification in a region-specific pattern ${ }^{58,59}$. In other words, diverse signalling effects can be achieved through different Notch receptor-ligand binding pattern. For example, Delta-like4 and Jagged1 are two reverse Notch ligands involved in angiogenesis, depending on their glycosylation status ${ }^{60}$. Delta-like4 may also influence the differentiation of pericytes from skeletal myoblasts ${ }^{61}$. Similarly, the intracellular domain of distinct Notch receptors may elicit different response when bound to the promoters of target genes ${ }^{62}$. On the other hand, Notch1 and Notch4 are mainly involved in VEC development. However, upon vascular injury, Notch1 and Notch3 instead play an important role in mature VSMC phenotype modulation ${ }^{63-65}$ and VSMC differentiation from adventitial stem/progenitor cells ${ }^{41}$. It is understandable that Notch receptors and ligands are expressed in advance by signalling cells that subsequently participate in Notch signalling. However, it remains unknown if these molecules are simultaneously upregulated in vascular cells and/or other cells within arterial vessels, prior to Notch signalling activation during vascular development and arterial remodelling.

\subsubsection{Canonical Wnt signalling pathway}


Wnt signalling pathways are divided into canonical ( $\beta$-catenin dependent) and non-canonical ( $\beta$-catenin independent) pathways. Canonical Wnt signalling pathway is highly conserved, and plays an irreplaceable role in maintaining stem cell function, cell fate specification, tissue homeostasis and organ development ${ }^{66,67}$, as well as in vascular cell specification. Notably, the functional involvement of Wnt signalling at different stages of embryonic development has not been entirely clear. As for mammals, the specification of somatic vascular cells normally undergoes four phases: undifferentiated PSCs, primitive streak, ectodermal neural crest or mesoderm, and somatic cells. The first step of PSC differentiation is the formation of primitive streak, where PSCs give rise to all endodermal and mesodermal lineages ${ }^{68}$. At this early stage of mesodermal development, transcript level of Wnt3 gene, along with Brachyury (T), eomesodermin (EOMES), FOXA2, MIXL1, and MESP1, are upregulated, all of which coordinate the induction and patterning of mesoderm ${ }^{68}$. Additionally, Wnt signalling pathway combined with BMPs, Activin/Nodal and FGFs, are momentous inducers for mesoderm formation ${ }^{68,69}$. More specifically, during the process of mesodermal induction from hPSCs, activation of $\beta$-catenin dependent Wnt signalling pathway by GSK3 inhibitors (CHIR99021 or CP21) and BMP signalling via BMP4 protein, push PSCs to commit into mesodermal lineages, enabling downstream vascular lineage specifications ${ }^{24}$. The vital role of Wht signalling pathway in facilitating mesoderm induction has been extensively studied, however, there are less studies on Wnt signalling-regulated vasculogenesis. More recently, a study has found that for human ESCs, the activation of Wnt signalling by GSK3 inhibition after mesodermal induction increased formation of vessel-like network, as well as the number of matured VECs ${ }^{70}$. They also reported that the over-expression of Wnt3a could lead to increased number of mature VECs, which was mediated by auto-upregulated transcription factor, Lef1, whereas the over-expression of Wnt8 was shown to impact the size of $\mathrm{VECs}^{70}$.

\subsubsection{Other important signalling pathways}

Sonic hedgehog (Shh) is an important component of the hedgehog family, it was demonstrated in zebrafish that Shh signalling pathway is crucial in lineage commitment of endothelial progenitors to form artery ${ }^{20}$. A communication model for Shh and Notch signalling was proposed as to be the underlying mechanism of arterial cell maturation ${ }^{71}$. Specifically, Shh initially binds to the G proteincoupled receptor Smoothened (SMO) and transmembrane receptor Patched (PTC), then it indirectly induces VEGF production in nearby somite, which subsequently activates Notch signalling pathway to boost arterial induction in zebrafish $^{72-75}$. Nevertheless, whether the same signalling interplay takes place in mammals is yet to be determined. Hippo signalling pathway, an extremely conserved kinase cascade, is conventionally regarded as a vital regulator in 
modulating cellular growth, organ size and other functions. Hippo signalling pathway plays an important role in injury-induced arterial remodelling. When the carotid artery is injured, the expression level of Yap is dramatically upregulated in VSMCs which in turn, promotes proliferation and migration of VSMCs $^{76}$. Moreover, an important role for Hippo signalling pathway in developmental and pathologic lymphangiogenesis ${ }^{77,78}$, angiogenesis ${ }^{79}$, SMC differentiation ${ }^{80}$, and coronary vasculature development ${ }^{81}$ has been welldocumented in the literature.

\subsubsection{Cross-talks between Wnt and Notch signalling pathway}

Although canonical Notch signalling pathway is highly conserved and selfcontained, it may also exert other signalling effects beyond its original role r2-85 $^{82}$ by cross-talking with other signalling pathways. For example, a study showed that membrane-bound Notch can cross-talk with Wnt signalling pathway and down-regulate the cytoplasmic level of unphosphorylated (activated) $\beta$-catenin protein in stem and colon cancer cells, by directly interacting with active $\beta$ catenin ${ }^{86}$. Additionally, during cerebrovascular VEC development, activation of the canonical Wnt signalling pathway can influence the amount of monocarboxylic acid transporter 1, which mediates the transportation of monocarboxylate fuels for brain VECs; whereas inhibition of the Notch signalling via $y$-secretase inhibitor antagonize the up-regulation of monocarboxylic acid transporter 1 , further supporting the functional importance of the cross communication between the canonical Notch and Wnt signalling pathway in VEC development ${ }^{87}$.

\subsection{PSC-based tissue engineering vascular graft (TEVG)}

Clinically, autologous and allogenic graftings are primarily limited by the narrow availability of native human blood vessels ${ }^{88,} 89$. However, ever since the introduction of vascular constructs built from biocompatible materials, synthetic vascular graft gradually rose to popularity as a main-stream player in most vessel-replacement therapies. Nonetheless, due to several post-operative concerns such as intimal hyperplasia, restenosis, immunologic rejection and post-operative infection ${ }^{89,90}$, further improvement or alternatives are urgently needed. Fortunately, the emergence of tissue engineering technologies have brought about new insights into circumventing these existing challenges ${ }^{89}$. Vascular engineered constructs are artificial blood vessel tissue mimetics that encompasses adequate mechanical durability, protein synthesis and cell types comparable to the naïve human vessels. Over the decade, numerous platforms have been developed with the aim to steadily produce patient-compatible TEVGs (Figure 3).

As an example, Manikowski and colleagues established a novel protocol to 
generate clinically applicable tissue engineered vascular constructs by casting the 3D hydrogel matrix onto the decellularized porcine small intestinal submucosa fixed in a custom-made metal frame. Human adipose tissuederived stromal cells (hASCs) and five different types of hVECs (HUVECs, human umbilical vein endothelial cells; hCEC, human cardiac endothelial cell; hPAEC, human pulmonary artery endothelial cell; iCell-ECs, iPSC derived endothelial cells from Cellular Dynamics International; hiPSC-ECs, human iPSC-derived endothelial cells) were co-cultured within the 3D hydrogel matrix. All co-culture systems demonstrated capacities to self-assemble and spontaneously form vessel-like networks which featured with small diameter lumens within the 3D hydrogel ${ }^{91}$ (Figure 3A). Meaningfully, this study brought new insights to the generation of TEVGs, which not only featured five types of hVECs, but also introduced an alternative mural cell hASCs, apart from SMCs and pericytes. Although hASCs are easily obtained from subcutaneous fats of patients, which mitigates the issues of cellular availability and immunogenicity against host ${ }^{92}$, the patients whom undergo this procedure are typically senior, with higher abundance of somatic cells exhibiting reduced proliferative capacities, comparing to younger patients; Secondly, the utilization of animal product as scaffolding materials still remained a huge drawback. Matrigel for example is still a controversial subject in clinical studies due to its batch-tobatch inconsistent immunogenicity and composition. Thus, the clinical adoption of this therapeutic strategy is still pending for extensive investigations.

Additionally, a recent study has also found that by co-culturing of iPSC-derived VSMCs and VECs under atheroprone hemodynamic context, the matured cells were highly similar to primary VSMCs and VECs ${ }^{93}$; In another study ${ }^{94}$, hiPSCderived VSMCs (hiPSC-VSMCs) were seeded onto a biodegradable scaffold and incubated under defined physical cues, more specifically, incremental increase of pulsatile radial distention at 110-120 beats/minute. The resulting hiPSC-VSMCs-based TEVG was engrafted into a nude rat, which remained patent after 4 weeks, with no longitudinal extension, radial dilation or teratoma formation, thus demonstrating excellent mechanical strength, durability and in vivo stability. Apart from radial distention stress, shear stress also plays a vital role in promoting iPSCs differentiation into VECs and facilitating VEC maturation.

Although hiPSCs can be readily reprogrammed from somatic cells of either patients or donors, several impeding factors are in play, such as difficulties in obtaining reprogrammable cells from patients with advanced age, time spent on laboratory procedures, and reduced effectiveness of cell-based therapy for patients with genetic disorders, altogether hindering the application of hiPSC technology in clinical practices. To circumvent these challenges, two novel approaches have been recently developed (Figure 3B): 1) Inspired by the 
immunologic tolerance phenomenon between the maternal immune system and paternal antigens during pregnancy ${ }^{95}$, researchers ${ }^{96}$ are now able to produce hypo-immunogenic iPSC from other young, health donors; more specifically, it was found that the syncytiotrophoblast cells, which constitute the interface between foetal tissue and maternal blood, express low level of major histocompatibility complex (MHC) class I and II, but up-regulated expression of CD47. CD47 is an omnipresent membrane protein that impedes phagocytosis by interacting with multiple cell surface receptors ${ }^{97}$. Based on these findings, Deuse et al ${ }^{96}$ adopted a versatile gene-editing tool, CRISPR-CAS9, to knock out $\beta 2$-microglobulin (B2m) gene, a configurational component of MHC class I, and Ciita gene, the primary modulator of $\mathrm{MHC}$ class II genes ${ }^{98}$, followed by the insertion of Cd47 gene sequence via lentivirus transfection. The B2 $\mathrm{m}^{-1-} / \mathrm{Ciita}^{-1-} / \mathrm{Cd} 47$-expressing hiPSCs featured hypo-immunogenicity with full developmental capacities ${ }^{96}$. Building on this, the usage of this hypoimmunogenic hiPSC in vascular graft should minimize host immune rejection, as well as efficiently prevent coagulation and restenosis post-implantation. Notably, this breakthrough in iPSCs technology can offer healthy, vigorous pluripotent cells to senior-age patients, or patients with inherent genetic deficits or systemic diseases; 2) Gene-editing tool can be utilized to correct the gene deficits in patient somatic cells, then reprogrammed to patient-specific iPSCs devoid of defective gene copies. In recent years, the revolutionary CRISPCase9 system has been increasingly used for efficient gene manipulation of embryonic cells, somatic cells or gametes ${ }^{99}$. Specifically, CRISPR/Cas9, a RNA-guided nuclease system, is far superior to other gene-editing tools, with low possibilities of non-specific targeting or incomplete suppression of the target genes, while showing significant improvements in precision for gene editing in hiPSCs ${ }^{100,101 .}$

Although vascular tissue engineering technologies have shown many promises, more systemic assessments are needed before the wide-spread application of TEVGs into clinical practice, such as mechanical durability, physiological functions, compatibility to host, cell plasticity, spatial-temporal degradation rate and cost-efficiency. More specifically, long-term in vitro cell culture may result in the gradual loss of cellular identities ${ }^{20,102}$, hence is more likely to induce cells with weaker functional capacities and higher heterogeneity comparing to their in vivo counterparts. Additionally, vascular cell specification and maturation are closely influenced by environmental cues, as the absence of which may lead to complicated epigenetic and genetic changes ${ }^{23,93}$. It is also dreadfully difficult to accurately control cell growth conditions in a correct time frame to recreate in vivo events. Moreover, with respect to the stage of cell development, the VECs in TEVGs are matured, therefore when engrafted, the plasticity of the engineered vessel is low and the integration with host blood vessel is less warranted. Finally, the artificial 3D biomimetic vessels used in transplant 
surgeries may cause blood anastomosis. Nevertheless, despite the countless technical improvements in experimental designs, tissue engineering approaches in general, does not faithfully recapitulate vessel development due to insufficient multicellular communication and hemodynamic interactions which provide critical clues for vascular development in naïve biological system.

\section{A new perspective: vascular organoids}

\subsection{Organoid technologies hold enormous potentials in clinical research and regenerative medicine}

Organotypic technology represents a tremendous stride in the refinements of tissue engineering techniques. Owning to the organoid's ability to self-organize under in vitro setups, it is now possible to generate stable, well-defined 3D structural mimics that resemble their in vivo counterparts in microstructures, cellular organizations and functional characteristics ${ }^{103}$. Comparing to traditional tissue engineering techniques, the advantages of using hPSCs/hiPSCs-derived organoids are: 1) highly versatile with downstream applications, 2) easy to visualize across all stages, 3) free of ethical concerns, 4) cost-effective, 5) ability to self-organize, 6) superior morphologies $\left.{ }^{104}, 7\right)$ remains genetically stable in long-term cultures ${ }^{105}$.

To date, organoids have been successfully generated from hESCs ${ }^{106}$, hiPSCs ${ }^{107}$, resident progenitor cells ${ }^{108}$ and patient-derived cancer cells ${ }^{109}$. Research platforms that utilized healthy organoids have revealed key information of organ-specific developmental pathways which were previously difficult to obtain with most in vivo models, such as the role of FGF signalling in gut formation ${ }^{110}$, the role of $\mathrm{SHH}$ signalling in lung-specific cell fate determination ${ }^{107}$, and fate-mapping of neural stem cells during brain development ${ }^{111}$. Alternatively, with disease-specific organoids derived from either patients or genetically modified cells, researchers were able to conduct mechanistic studies on disease progression, identifying disease-related genes, and assessing drug toxicity/efficacy in a high-throughput manner, as demonstrated in a recent study that outlined the causal link between infectious disease and microcephaly using brain organoid ${ }^{112}$, or another study which predicted gene-associated drug response in cystic fibrosis patients ${ }^{113}$. However, despite being met with overwhelming enthusiasm by most of the research communities, organoid-based research is still at the fetal stage of development and is faced with numerous practical challenges. Whether organoids can truly become the 'game changer' in regenerative medicine that many have envisaged is still an open question.

Undoubtedly, organoid technologies also open up new avenues in the field of 
regenerative medicine, as an alternative to tissue/organ engraftments for patients who had sustained non-recoverable loss of vital organs. Although conceptually promising, the efficacy and long-term safety of organoid-based therapies are still pending evaluation due to insufficient human studies; in other words, the wide-spread clinical integration of organoid technologies for tackling degenerative diseases still faces significant constraints (Table 2). Most importantly, the production of human organoids has to be in compliance with good manufacturing practices (GMP) criteria, that are universal for all clinical products $^{114}$ prior to clinical utilizations. In any case, organoid-based regenerative studies are to be further expanded and diversified in spite of the remarkable progress thus far. The positive results produced by animal-based organoid transplant models such as colon epithelium ${ }^{115}$, cerebral cortex ${ }^{116}$ and liver lobules ${ }^{117}$, indeed make attractive headlines and fill the hearts with overwhelming confidents, but we still face numerous obstacles before the full potential of organoid technologies are harnessed.

\subsection{The making of vascular organoids}

During embryonic development, formation of the circulatory system precedes other system developments in all vertebrate embryos ${ }^{118}$. The need for transporting nutrients and expelling waste heavily outweighs the rest, since passive oxygen diffusion is no longer capable of sustaining rapid fetal growth during late-gastrulation ${ }^{119}$. Vasculogenesis and angiogenesis are crucial processes that govern the development of embryonic vasculatures. Whereas vasculogenesis describes the de novo formation of primary capillary plexus from the fusion of blood islands - small aggregates of endothelial precursor cells that are able to form a hierarchical networks of primitive blood vessels ${ }^{120}$, angiogenesis describes the refinement of the vasculatures, via extensive remodelling and expansion of capillary networks, thus promoting the formation of a mature circulatory system ${ }^{121}$. By the same token, reconstruction of blood vessel-like structures ex vivo is a comparable process to normal vascular development, where the end-product should adequately recapitulate structural organizations of innate vasculatures, sufficient in functional capacity for carrying out physiological roles, and promote host tissue integration without adverse effects ${ }^{122}$.

Drawing inspirations from established 2D induction methods and 3D co-culture assays, Wimmer et al streamlined their approach and designed a multi-step protocol that successfully gave rise to hPSC-derived vascular organoids in vitro (Figure 4), without the need to independently induce and purify multiple populations of homogenous vascular cells. Structurally, hPSC-derived vascular organoid forms a self-contained, interconnected 3D microvascular network composed of VECs, pericytes and a continuous layer of basement membrane ${ }^{123}$. In a previous study, Patsch et al, reported that hiPSCs could be 
directed toward the mesodermal lineage via Wnt activation and BMP4 stimulation, followed by uninterrupted VEGF-A and Forskolin treatments for vascular lineage specification ${ }^{24}$. Instead of starting off with hPSCs in monolayer cultures, Wimmer et al selected ultra-low attachment plates which allowed hPSCs to self-aggregate. When embedded within 3D collagen I-Matrigel gels, these hPSC aggregates were able to develop into stable, branching, vessellike endothelial networks under the treatment of VEGF-A, FGF-2 and Fetal bovine serum (FBS). Amongst many highlights, there were several key findings that took the spotlight: 1) isolated vascular organoids could be maintained individually in 96-well plate for a long duration, 2) in vivo transplantation confirmed excellent vascular integration, and demonstrated incredible stability for $>6$ months post-transplantation in SCID mice, 3) upon dissection, lumen-like cavities were observed within sprouting microvasculature, as well as vessellike cellular organizations where VECs formed luminal cavity, tightly associated with pericytes and enveloped by an outer layer of ECM proteins, 4) vascular organoids were composed of multiple cell types, including pericytes, VECs, mesenchymal stem-like cells and haematopoietic cells, 5) organotypic cultures displayed excellent angiogenic potentials, 6) microvasculature formation was observable despite using a small number $(n=2-5)$ of vascular organoids.

Undeterred by the simplicity and efficiency of Wimmer et al's methodology, one glaring constraint, which also happens to be a major bottleneck for the majority of organotypic differentiation protocols ${ }^{124}$, was the issue with reproducibility and scalability; more specifically, the formation of hPSC-aggregates (EB formation) in static suspensions was undoubtedly a great starting point for downstream lineage specifications, whilst providing the hPSCs with the highest level of organizational freedom, as well as rich intercellular communications; however, there were no additional measures implemented during the early stages of differentiation, in order to reduce the likelihood of unwanted cellular heterogeneity. The absence of cell-sorting procedures also does not bode well for the overall reproducibility of the protocol, thus, the incorporation of technique such as fluorescence assisted cell sorting would greatly benefit the overall scalability and reproducibility of this protocol; additionally, the protocol did not address the implementation of a robust quantitative quality control step, which is necessary to meet GMP standards and should be put in place as a way to combat the potential impacts of interexperimental or intercolonial variations ${ }^{125}$. In any case, the establishment of a rigorous quality control guideline is key for fulfilling the overall potentials of vascular organoid technology in both clinical research and therapeutic applications.

\subsection{Vascularization of other complex tissue organoids}


A lack of vascularization has always been a major roadblock for de novo generation of functional, viable biomimetic tissue constructs that are suitable for clinical and research applications. Consequently, vascularization strategies were incorporated for the purpose of circumventing growth arrests commonly seen in large organotypic cultures. Under the absence of de novo vasculatures, the generation of a functional organ is often impeded by the formation of necrotic cores, and subsequent loss of proliferative capacities ${ }^{126}$. In light of recent technological advancements in the field of tissue engineering, construction of in vitro vasculatures at various scales can be achieved by a variety of techniques, including 3D bioprinting, sacrificial networks, 2-photon fabrication, subtractive fabrication and many more ${ }^{127}$. While state-of-the-art biofabrication techniques can impose appropriate structural patterns for organoid vascularization, Wimmer et al provided a simplistic hPSC-based platform that are capable of giving rise to self-organizing, vascularized organoids in vitro; similarly, Pham et al also achieved tremendous success in establishing highly vascularized, self-organizing brain organoids by co-culture with VECs derived from patient iPSC with remarkable longevity ${ }^{128}$. Here, we briefly discussed the recent advancement of vascularization of complex human organoids using hPSC-based vascularization strategies (Figure 5).

\subsubsection{Vascularization of human cerebral organoids}

Whole-brain organoids were first introduced by Lancaster et al, although the organoids could remain viable for over a year under controlled environment, absence of vasculature formation directly contributed to its lacklustre expansion capacity, as well as inadequate neural tissue patterning ${ }^{129}$ (Figure 5a). Whilst it has been proven that the established cerebral organoids is capable of integrating into host brain tissue, generating functional microvasculatures, neuronal tissues, and even producing synaptic activities ${ }^{130}$, the inclusion of mouse as host environment for vascularization does not necessarily translate to other host organisms. To overcome this, Pham et al re-embedded the nonvascularized cerebral organoids generated from hiPSCs with 250,000 ECs derived from the same hiPSC line (Figure $\mathbf{5 b}$ ); as a result, robust vascularization of re-embedded organoids was observed after 2 weeks, as demonstrated by robust infiltrations of $\mathrm{CD} 31^{+}$cells into the cerebral organoids and subsequent formations of tubular structures within these organoids. Consequently, vascularized cerebral organoids demonstrated superior survivabilities in vivo and deep penetrations into the STEM121+ core region, which were absent in non-vascularized organoids. Similarly, Wörsdörfer et al established a hiPSC-based co-culture method that encouraged formation of heirachical, branching vascular structures within iPSC-derived Sox $1^{+}$neural spheroids ${ }^{131}$ (Figure 5c). Upon close inspection, it was reavealed that iPSCderived mesenchymal progenitor cells spontaneously integrated with neural 
spheroids and gave rise to mesenchymal tissues, which later matured into sprouting endothelial networks comprised of CD31+ VECs, finalized with lumen formation as well as recruitment of periendothelial cell (resembling myoendothelial junctions ${ }^{132}$. Morevoer, Cakir et al vascularized human cortical organoids by incorporating ETV2 (human ETS variant 2, a transcription factor when ectopically expressed can induce endothelial differentiation ${ }^{133}$ )overexpresing human VECs into early embryoid body cultures (Figure 5d). Whereby the presence of ETV2-expressing cells on day 18 had greatly enhanced the formation of vasculature-like structures during subsequent neural and endothelial differentiation, with improved functional characteristics as observed in the mature microvascular assemblies ${ }^{134}$. It should be noted that although these strategies achieved vascularization via different approaches, they are principally similar in differentiation methodologies - directed differentiation that also incorportated other cell types. The advantages are of course the freedom of controlling external stimuli while allowing intercellular communications between different cell types; however it should be noted that co-culture organotypic setup may result in restricted access to external differentiation factors ${ }^{135}$; the use of genetically modified hPSC may also have subtle ramifications in organoid functions, or gene expressions profiles, which should be scrutized under rigorous quality control procedures.

Last but not least, Ham et al generated blood vessel-like networks within iPSCderived cerebral organoids in absence of iPSC-derived progenitors cells, displaying outstanding architectural, functional and biochemical characteristics similar to that of blood-brain barrier seen in live organisms (Figure 5e). This was achieved by incorporating human recombinant VEGF during embryoid body culture and neural differentiation, followed by a 2-month treatment of Wnt7a in the presence of VEGF, which had successfully induced vessel maturation and microvascular-network infiltration in cerebral organoids ${ }^{136}$. However, although the strategy offered cell-type diversity with some degree of chemical-based control, the unpredictable nature of allowing EB formation at early differentiation stage means high variability and heterogeneity, which might present at some point of organoid development and pose a significant challenge for achieving large scale reproductions.

\subsubsection{Vascularization of human kidney organoids}

Analogous to the brain, kidneys also require extensive vascular networks in order to achieve functional competence and homeostasis. Whereas previously established protocols may excel in generating iPSC-derived renal organoids with distinguishable, nephron-like 3D organizations of renal cells in static in vitro cultures $^{137-139}$, a lack of vascularization and insufficient glomerular/tubular 
maturation remained fundamental challenges for deriving functionally mature renal organoids. Despite evidences of endothelial cells being detected inside established renal organoids ${ }^{140}$, an absence of blood vessel-like organization of vascular cells indicated no meaningful glomerulus infiltration or tubular compartmentalization, effectively, zero functionality.

Interestingly, Homan et al employed a dynamic culture setup that could generate vascularized renal organoids with perfusable lumen space, consisting of PECAM1+ mature endothelia and recruited PDGFR $\beta^{+}$pericyte-like MCs ${ }^{141}$. By semi-embedding developing renal organoids onto a gelatin-fibrin (Gelbrin)coated millifluidic chip, Homan et al were able to observe markedly improved tubular epithelia maturation, glomerular vascularization and overall functional maturation of kidney organoids, comparing with the original hPSC-based method reported by Morizane et $a \Gamma^{142}$. Despite this flow-enhanced vascularization being achieved with only a collection of defined chemomechanical parameters, additional signalling components may still be required to ensure stable generation of perfusable renal vascular network. Moreover, this protocol showed no meaningful coordination in patterning of different nephron cell components during organoid development, marking a stark contrast to normal kidney development in vivo.

Recently, Low et al introduced a static induction platform that could robustly generate vascularized renal organoids via dose-dependent exposures to Wnt signalling activator, GSK3 inhibitor CHIR99021, at different stages of organoid differentiation ${ }^{143}$. Specifically, following the induction of intermediate mesoderm (IM) progenitors, Low et al adapted two medium recipes, namely in addition to $50 \mathrm{ng} / \mathrm{mL}$ FGF9 (basal medium), $3 \mu \mathrm{M}$ or $1 \mu \mathrm{M}$ CHIR99021 were also supplemented chronologically. The differentiation medium containing $3 \mu \mathrm{M}$ CHIR99021 were used to 'prime' the IM for lineage commitment (termed 'Priming CHIR') for two days, $1 \mu \mathrm{M}$ CHIR99021 were then supplemented in the basal medium at day 14 of differentiation, which were then 'pulsed' for a duration of 1-10 days (termed 'Patterning CHIR'). As a result, the final organoids at day 24 exhibited remarkable proximal-distal patterning of kidney tissues, as well as sufficient infiltrations of vasculatures comprised of CD $31^{+} /{\text {CD } 34^{+}}^{+}$endothelial cells ${ }^{143}$. However, similar to the conundrums faced by human brain organoids, the concerns regarding the overall reproducibility and scalability of static, unguided differentiation methodology persists.

\subsubsection{Vascularization of other human organoids}

In addition to human cerebral and kidney organoids, other complex organotypic models such as human cardiac, liver, pancreatic and intestinal organoids could also benefit from increased cellular complexity. The two most common approaches are co-culture methods and transplantation assays, as the 
inclusion of appropriate supporting cell types or exposures to in vivo environments could enhance organoid complexities, when compared to traditional mono-culture setup ${ }^{144}$; these approaches are often implemented for most vascularization strategies of other human organoids.

For example, conventional hPSC-derived cardiac organoids were obtained through EB-mediated cardiac differentiation, which often suffered from poor spatial arrangements of cardiomyocytes (CMs) and stromal cells, as well as lacking capillary network formation due to the absence of biophysical stimuli ${ }^{145}$. Instead, when hPSC-derived CMs (hPSC-CMs) were mixed with ventricular cardiac fibroblasts and HuVECs at a ratio that similar to the cell ratios in developing hearts (5:4:1) and seeded onto a micro-fabricated insert with appropriate biophysical parameters, the cardiac organoids closely resembled native tissue architectures, forming microvascular networks comprised of CD31+ VECs, while also exhibiting contractile and electrophysiological properties when matured ${ }^{146-148}$. These newly developed and vascularized human cardiac organoids could be cultured in a 96-well format, with minimal requirement of tissue handling and allowing for real-time analysis of cardiac contractile parameters, thus enabling high-content screening of mature hPSC$\mathrm{CMs}$, elucidating underlying mechanisms of human cardiomyocyte cell-cycle arrest, proliferation and apoptosis, predicting drug cardiac toxicology, and using as drug discovery pipelines to identify the most efficacious activators of cardiac regeneration ${ }^{149}$.

For human hepatic organoids, many vascularization strategies abide by the same core elements - a Matrigel-assisted 3D co-culture of hPSC-derived hepatocytes, source of ECs and mesenchymal stromal cells (MSCs). Interestingly, the source of ECs may vary between human umbilical vein endothelial cells $\mathbf{s}^{150}$, human adipose microvascular endothelial cells $\mathbf{s}^{151}$ and hPSC-derived ECs ${ }^{152}$; whereas MSCs may vary from human bone marrowderived $\mathrm{MSCs}^{150}$, hPSC-derived $\mathrm{MSCs}^{153}$ to human dental pulp-derived MSCs $^{154}$. In general, 3D co-culturing of hPSC-derived hepatocytes, ECs and MSCs could facilitate the in vitro self-organizations and subsequent maturations into hepatic spheroids, completed with self-contained microvascular networks comprising of $\mathrm{CD} 31^{+}$endothelial cells ${ }^{155}$. Additionally, transplantation of hepatic organoid into immune-compromised mice could promote further maturations of the $\mathrm{CD} 31^{+}$endothelial networks and improve overall tissue architectures ${ }^{156}$. Similarly, vascularized pancreatic organoids were generated by 3D co-culturing of human isolated islet cells, ECs and MSCs, embedded in scaffolding materials such as hydrogels; further maturations of the self-contained microvascular networks were observed post engraftments ${ }^{157}$. However, formation of microvascular networks was not observed when human isolated islet cells were replaced with hPSC-derived pancreatic progenitor cells, 
as no endothelial networks were constructed ${ }^{158}$; last but not least, the vascularization strategies of hPSC-derived human intestinal organoids ${ }^{159}$ were strictly confined to in vivo models, more specifically, de novo formation of microvascular network was only observable in a form of host vessel integration 160.

\subsection{Applications of vascular organoids technology in vasculopathies research}

One of the potential applications of vascular organoid cultures, as Wimmer et al described, is to study the pathophysiological development of diabetic vasculopathy, and to validate existing pharmaceutical interventions for this disease. To their surprise, the organotypic culture was able to faithfully recapitulate the thickening of the basement membrane of distal microvascular network - a pivotal pathological event of diabetic vasculopathy observed in human patients ${ }^{161}$. It was achieved by conditioning the organotypic cultures with a combination of inflammatory cytokines and high level of glucose. Further in vivo studies also confirmed similar microvascular abnormalities in host mice. Importantly, the 96-well organotypic cultures enabled high-throughput drug screenings and led to the subsequent discovery of critical signalling effectors, DLL4 and NOTCH 3, both are key drivers of the thickening of basement membrane commonly observed in diabetic vasculopathy ${ }^{162,163}$.

The implications of this approach are enormous (as shown in Figure 6). Keeping in mind that vasculopathies are manifestations of structural or functional ailments of either large or small blood vessels, a culture system that promotes formation of functional, vessel-like networks from an endless supply of precursor cells in vitro, can potentially revolutionize the field of vascular research. For example, healthy vascular organoid is ideal for mechanistic studies of pro-/anti-angiogenic factors, as insufficiency of angiogenesis cause disruption of normal vessel homeostasis, resulting in ischemia-related diseases such as myocardial infraction, vascular degeneration and neural degeneration ${ }^{164}$. Moreover, unmodulated angiogenesis is responsible for tumour growth, metastasis and evolution. Additionally, abnormal vascularization is also responsible for inflammatory disorders, atherosclerosis and blindness ${ }^{165}$. Furthermore, disease-specific vascular organoids derived from either patient or genetically modified hiPSCs can provide a robust, highthroughput drug screening platform for personalized therapies. With rapid generation (11 days) and a 96 -well culture format, a large number of patientspecific vascular organoids can be generated simultaneously, enabling researchers to discern disease-related gene effectors, via a discovery-based approach.

Endothelial dysfunction is a highly complex vascular disorder and it is known 
for its role as an initiator of development of atherosclerosis, hypertension, arterial stiffening and systemic vessel-related complications. Traditionally, in vitro assessment of endothelial functions are performed in monolayer cell cultures $^{166}$ and whole-organ cultures ${ }^{167}$. Cell cultures are commonly used for discovering signalling pathways and characterisations of endothelial response to endothelium derived relaxing factors; whereas whole-organ cultures are often deployed for functional studies within the context of an organ. Despite the significant contributions made by whole-organ cultures throughout the past decades of vascular research, very little progress was achieved in regard to overcoming a number of deep-rooted flaws, including organ deterioration due to ischemia and lack of perfusion, difficulties in preserving organ functions, and overwhelming economic burdens. In recent times, applications of hiPSC/hPSC derived microvascular constructs in modelling endothelial functions have gained tractions, as more and more robust modelling techniques are being reported, including the human blood-brain barrier ${ }^{168}$, 3D microvasculatures ${ }^{169}$, and 3D vascularized renal tissue ${ }^{170}$. Organoid technologies are therefore highly applicable in modelling endothelial dysfunctions, measuring responses to vasoconstrictors/vasodilators, using either patient-derived iPSCs or gene edited iPSCs, in a rapid, high-throughput fashion.

As described by Wimmer et al, transplantation of hiPSC-derived vascular organoid in immunodeficient, diabetic mice faithfully recapitulated key pathological event of diabetic vasculopathy in vivo. Thus, organotypic transplant can potentially serve as an efficient, highly versatile in vivo platform for prospective genetic studies of chronic vascular diseases, as well as modelling facets such as inflammation response, immune cell interactions, vessel permeability, lipid interactions, and vascular remodelling. Additionally, a standardized host model can provide retrospective evidence for drug efficacy, biomarker validities and other vascular disease-related parameters, or produce complementary results for a range of preclinical studies.

\section{Pressing challenges and future directions}

Although vascular organotypic technology represents a tremendous stride in generating patient-specific TEVGs, using hPSC-derived vascular cells or other cell types to create engineered vascular grafts and organoids in vitro is at the very early stages of development and far from being ready for clinical applications (Table 2). One of the major challenges of vascular organoid technologies is the lack of perfusion of blood under in vitro settings. Conventionally, perfusion of blood is only achievable via transplantation into a live organism, which alleviates problems such as nutrient gradient and waste 
accumulation in long-term 3D cultures. The inclusion of perfused blood could drastically improve the longevity of vascular organoid cultures, as seen in renal organoid cultures. It could also incorporate key functional parameters of native blood vessels, as it is evident that haematopoietic cells, immune cells and circulating vascular progenitor cells all contribute to the homeostasis of vascular networks ${ }^{171}$. Mechanobiological forces created by blood perfusion are also equally important in maintaining the viability of vasculatures ${ }^{172}$. Moreover, since circulating bone marrow-derived cells, such as leukocytes and monocytes, are facilitators of the inflammatory responses localized around pathological lesions, as well as the systemic response hallmarked in atherosclerosis, inclusion of blood and/or selected immune cells in organotypic cultures could enhance translatability and provide responses that are more reflective of the naïve physiological environment, as demonstrated by Noonan et al in their tri-cellular 2D cultures ${ }^{173}$.

Cellular heterogeneity in organotypic cultures is frequently regarded as a significant improvement by most research communities. In actuality, a culture of heterogeneous population of cells and its subsequent response to drugs can be somewhat unpredictable and difficult to reproduce, even more so in case of vascular organoids, as evidenced by the fact that more than two subsets of cells were observed; conversely, the development of organotypic cultures with varied cellular compositions, such as cardiac tissues, can be extremely challenging due to the complexities of functional cell types and relevant spatial organizations ${ }^{174}$, the precise ratios of each heterogeneous populations ${ }^{175}$, differences in transcriptomes between hPSC-derived cardiac \& vascular cells and their native cells ${ }^{176}$, as well as any potential impacts they may exert; finally, clonal drift is another inescapable event that has the potential of severely impacting the overall reproducibility of organotypic cultures (termed 'organoid heterogeneity'). To emphasize, there is still a great deal of knowledge required to perpetuate advancements and refinements of vascular organoid technologies.

The use of animal products, such as serum or tissue scaffolds with animal origins, is still an existing flaw in most current setups of organotypic cultures, including the protocol reported by Wimmer et al, which also used Collagen IMatrigel and FBS to encourage formation of microvascular networks and to improve survivability. Inclusion of animal products can potentially lead to abnormal growth, premature differentiation or impeded formation of microvasculatures, due to batch-to-batch variations of animal products, which ultimately manifest as discrepancies among different studies. Such negative impacts may also affect drug screening results or any downstream applications. Accordingly, to meet Good Manufacturing Practice (GMP) standards, 
improvements needed to be made by using synthetic, biocompatible alternatives.

Finally, undeterred by the enormous strides made in terms of translatability, relevancy and scalability of in vitro modelling platforms, complex in vitro systems would most inevitably suffer from difficulties in data integration, interpretation and application, not to mention the increased likelihood of anomalies due to the inherent unpredictability of different cell types residing in a constructed microenvironment. Computational modelling analysis can therefore be incorporated into organotypic culture setups as a mean to reliably extrapolate complex datasets of genomic, proteomic and metabolic information, and transform these datasets into mathematical models that are accurate representations of native biological system. Additionally, although it was believed that human-based modelling platforms are vastly superior in predicting human responses than animal-based models, implementation of computational models is most definitely beneficial for validating screening outcomes from organotypic cultures, as well as predicting relevant clinical endpoints.

In conclusion, although current vascular organoid technologies still represents a primitive version of a powerful platform for studying both functional and genetic aspect of human vasculopathies, they have exceptional potentials in studying disease etiology, vascular development, high-throughput drug screening under simplistic set up, and providing unlimited reliable vascular grafts for life-threating vascular diseases.

\section{Funding}

This work was supported by British Heart Foundation (PG/15/11/31279, $P G / 15 / 86 / 31723$, and $P G / 16 / 1 / 31892)$. This work forms part of the research portfolio for the National Institute for Health Research Biomedical Research Centre at Barts.

Acknowledgement: None

Conflict-of-interest disclosure: None 


\section{Reference:}

1. Feigin VL, Roth GA, Naghavi M, Parmar P, Krishnamurthi R, Chugh S, Mensah GA, Norrving B, Shiue I, Ng M, Estep K, Cercy K, Murray CJL, Forouzanfar MH. Global burden of stroke and risk factors in 188 countries, during 1990-2013: a systematic analysis for the Global Burden of Disease Study 2013. Lancet Neurol 2016;15:913-924.

2. Bonaca MP, Creager MA. Pharmacological treatment and current management of peripheral artery disease. Circ Res 2015;116:1579-1598.

3. Spence JD, Dresser GK. Overcoming Challenges With Statin Therapy. J Am Heart Assoc 2016;5.

4. Berliner JA, Navab M, Fogelman AM, Frank JS, Demer LL, Edwards PA, Watson AD, Lusis AJ. Atherosclerosis: basic mechanisms. Oxidation, inflammation, and genetics. Circulation 1995;91:2488-2496.

5. Rafieian-Kopaei $M$, Setorki $M$, Doudi M, Baradaran A, Nasri H. Atherosclerosis: process, indicators, risk factors and new hopes. Int J Prev Med 2014;5:927-946.

6. Ghallab A. In vitro test systems and their limitations. Excli j 2013;12:1024-1026.

7. Jopling C, Sleep E, Raya M, Marti M, Raya A, Izpisua Belmonte JC. Zebrafish heart regeneration occurs by cardiomyocyte dedifferentiation and proliferation. Nature 2010;464:606-609.

8. Thomson JA, Itskovitz-Eldor J, Shapiro SS, Waknitz MA, Swiergiel JJ, Marshall VS, Jones JM. Embryonic stem cell lines derived from human blastocysts. Science 1998;282:1145-1147.

9. Takahashi K, Tanabe K, Ohnuki M, Narita M, Ichisaka T, Tomoda K, Yamanaka S. Induction of pluripotent stem cells from adult human fibroblasts by defined factors. Cell 2007;131:861-872.

10. Howard D, Buttery LD, Shakesheff KM, Roberts SJ. Tissue engineering: strategies, stem cells and scaffolds. J Anat 2008;213:66-72.

11. Bertucci TB, Dai G. Biomaterial Engineering for Controlling Pluripotent Stem Cell Fate. Stem Cells Int 2018;2018:9068203.

12. Jana S, Cooper A, Zhang M. Chitosan scaffolds with unidirectional microtubular pores for large skeletal myotube generation. Adv Healthc Mater 2013;2:557-561.

13. Wang S, Mo XM, Jiang BJ, Gao CJ, Wang HS, Zhuang YG, Qiu LJ. Fabrication of smalldiameter vascular scaffolds by heparin-bonded $\mathrm{P}(\mathrm{LLA}-\mathrm{CL})$ composite nanofibers to improve graft patency. Int J Nanomedicine 2013;8:2131-2139. 
14. Smeriglio P, Lai JH, Yang F, Bhutani N. 3D Hydrogel Scaffolds for Articular Chondrocyte Culture and Cartilage Generation. J Vis Exp 2015.

15. Zhang YS, Aleman J, Shin SR, Kilic T, Kim D, Mousavi Shaegh SA, Massa S, Riahi R, Chae S, Hu N, Avci H, Zhang W, Silvestri A, Sanati Nezhad A, Manbohi A, De Ferrari F, Polini A, Calzone G, Shaikh N, Alerasool P, Budina E, Kang J, Bhise N, Ribas J, Pourmand A, Skardal A, Shupe T, Bishop CE, Dokmeci MR, Atala A, Khademhosseini A. Multisensor-integrated organs-on-chips platform for automated and continual in situ monitoring of organoid behaviors. Proc Natl Acad Sci U S A 2017;114:E2293-e2302.

16. Badylak SF, Taylor D, Uygun K. Whole-organ tissue engineering: decellularization and recellularization of three-dimensional matrix scaffolds. Annu Rev Biomed Eng 2011;13:27-53.

17. Shin D, Garcia-Cardena G, Hayashi S, Gerety S, Asahara T, Stavrakis G, Isner J, Folkman J, Gimbrone MA, Jr., Anderson DJ. Expression of ephrinB2 identifies a stable genetic difference between arterial and venous vascular smooth muscle as well as endothelial cells, and marks subsets of microvessels at sites of adult neovascularization. Dev Biol 2001;230:139-150.

18. Wang HU, Chen ZF, Anderson DJ. Molecular distinction and angiogenic interaction between embryonic arteries and veins revealed by ephrin-B2 and its receptor Eph-B4. Cell 1998;93:741-753.

19. Jones EA. The initiation of blood flow and flow induced events in early vascular development. Semin Cell Dev Biol 2011;22:1028-1035.

20. Niklason L, Dai G. Arterial Venous Differentiation for Vascular Bioengineering. Annu Rev Biomed Eng 2018;20:431-447.

21. Zhang SC, Wernig M, Duncan ID, Brustle O, Thomson JA. In vitro differentiation of transplantable neural precursors from human embryonic stem cells. Nat Biotechnol 2001;19:1129-1133.

22. Srinivasan A, Toh YC. Human Pluripotent Stem Cell-Derived Neural Crest Cells for Tissue Regeneration and Disease Modeling. Front Mol Neurosci 2019;12:39.

23. Li X, Xu R, Tu X, Janairo RRR, Kwong G, Wang D, Zhu Y, Li S. Differentiation of Neural Crest Stem Cells in Response to Matrix Stiffness and TGF-beta1 in Vascular Regeneration. Stem Cells Dev 2020;29:249-256.

24. Patsch C, Challet-Meylan L, Thoma EC, Urich E, Heckel T, O'Sullivan JF, Grainger SJ, Kapp FG, Sun L, Christensen K, Xia Y, Florido MH, He W, Pan W, Prummer M, Warren CR, Jakob-Roetne R, Certa U, Jagasia R, Freskgard PO, Adatto I, Kling D, Huang P, Zon LI, Chaikof EL, Gerszten RE, Graf M, lacone R, Cowan CA. Generation of vascular 
endothelial and smooth muscle cells from human pluripotent stem cells. Nature cell biology 2015;17:994-1003.

25. Orlova VV, Drabsch Y, Freund C, Petrus-Reurer S, van den Hil FE, Muenthaisong S, Dijke PT, Mummery CL. Functionality of endothelial cells and pericytes from human pluripotent stem cells demonstrated in cultured vascular plexus and zebrafish xenografts. Arterioscler Thromb Vasc Biol 2014;34:177-186.

26. Huang Y, Chen X, Che J, Zhan Q, Ji J, Fan Y. Shear Stress Promotes Arterial Endothelium-Oriented Differentiation of Mouse-Induced Pluripotent Stem Cells. Stem Cells Int 2019;2019:1847098.

27. Ohtani-Kaneko R, Sato K, Tsutiya A, Nakagawa Y, Hashizume K, Tazawa H. Characterisation of human induced pluripotent stem cell-derived endothelial cells under shear stress using an easy-to-use microfluidic cell culture system. Biomed Microdevices 2017;19:91.

28. Kane NM, Meloni M, Spencer HL, Craig MA, Strehl R, Milligan G, Houslay MD, Mountford JC, Emanueli C, Baker AH. Derivation of endothelial cells from human embryonic stem cells by directed differentiation: analysis of microRNA and angiogenesis in vitro and in vivo. Arterioscler Thromb Vasc Biol 2010;30:1389-1397.

29. Xiao Q, Pepe AE, Wang G, Luo Z, Zhang L, Zeng L, Zhang Z, Hu Y, Ye S, Xu Q. Nrf3$\mathrm{Pla} 2 \mathrm{~g} 7$ interaction plays an essential role in smooth muscle differentiation from stem cells. Arteriosclerosis, thrombosis, and vascular biology 2012;32:730-744.

30. Pepe AE, Xiao Q, Zampetaki A, Zhang Z, Kobayashi A, Hu Y, Xu Q. Crucial role of nrf3 in smooth muscle cell differentiation from stem cells. Circulation research 2010;106:870-879.

31. Xiao Q, Luo Z, Pepe AE, Margariti A, Zeng L, Xu Q. Embryonic stem cell differentiation into smooth muscle cells is mediated by Nox4-produced H2O2. American journal of physiology Cell physiology 2009;296:C711-723.

32. Wang RN, Green J, Wang Z, Deng Y, Qiao M, Peabody M, Zhang Q, Ye J, Yan Z, Denduluri S, Idowu O, Li M, Shen C, Hu A, Haydon RC, Kang R, Mok J, Lee MJ, Luu HL, Shi LL. Bone Morphogenetic Protein (BMP) signaling in development and human diseases. Genes Dis 2014;1:87-105.

33. Rahman MS, Akhtar N, Jamil HM, Banik RS, Asaduzzaman SM. TGF-beta/BMP signaling and other molecular events: regulation of osteoblastogenesis and bone formation. Bone Res 2015;3:15005.

34. Zhang L, Jin M, Margariti A, Wang G, Luo Z, Zampetaki A, Zeng L, Ye S, Zhu J, Xiao Q. Sp1-dependent activation of HDAC7 is required for platelet-derived growth factor- 
BB-induced smooth muscle cell differentiation from stem cells. The Journal of biological chemistry 2010;285:38463-38472.

35. Margariti A, Xiao Q, Zampetaki A, Zhang Z, Li H, Martin D, Hu Y, Zeng L, Xu Q. Splicing of HDAC7 modulates the SRF-myocardin complex during stem-cell differentiation towards smooth muscle cells. Journal of cell science 2009;122:460-470.

36. Zeng L, Xiao Q, Margariti A, Zhang Z, Zampetaki A, Patel S, Capogrossi MC, Hu Y, $\mathrm{Xu} \mathrm{Q}$. HDAC3 is crucial in shear- and VEGF-induced stem cell differentiation toward endothelial cells. The Journal of cell biology 2006;174:1059-1069.

37. Xiao Q, Zeng L, Zhang Z, Margariti A, Ali ZA, Channon KM, Xu Q, Hu Y. Sca-1+ progenitors derived from embryonic stem cells differentiate into endothelial cells capable of vascular repair after arterial injury. Arteriosclerosis, thrombosis, and vascular biology 2006;26:2244-2251.

38. Zhao H, Wen G, Huang Y, Yu X, Chen Q, Afzal TA, Luong le A, Zhu J, Ye S, Zhang L, Xiao $Q$. MicroRNA-22 regulates smooth muscle cell differentiation from stem cells by targeting methyl CpG-binding protein 2. Arteriosclerosis, thrombosis, and vascular biology 2015;35:918-929.

39. Luo Z, Wen G, Wang G, Pu X, Ye S, Xu Q, Wang W, Xiao Q. MicroRNA-200C and 150 play an important role in endothelial cell differentiation and vasculogenesis by targeting transcription repressor ZEB1. Stem cells 2013;31:1749-1762.

40. Yu X, Zhang L, Wen G, Zhao H, Luong LA, Chen Q, Huang Y, Zhu J, Ye S, Xu Q, Wang $W$, Xiao $Q$. Upregulated sirtuin 1 by miRNA-34a is required for smooth muscle cell differentiation from pluripotent stem cells. Cell death and differentiation 2015;22:1170-1180.

41. Yang F, Chen Q, Yang M, Maguire EM, Yu X, He S, Xiao R, Wang CS, An W, Wu W, Zhou $Y$, Xiao $Q$, Zhang L. Macrophage-derived MMP-8 determines smooth muscle cell differentiation from adventitia stem/progenitor cells and promotes neointima hyperplasia. Cardiovascular research 2020;116:211-225.

42. Fang C, Wen G, Zhang L, Lin L, Moore A, Wu S, Ye S, Xiao Q. An important role of matrix metalloproteinase- 8 in angiogenesis in vitro and in vivo. Cardiovascular research 2013;99:146-155.

43. Xiao $Q$, Zhang $F$, Lin L, Fang C, Wen G, Tsai TN, Pu X, Sims D, Zhang Z, Yin X, Thomaszewski B, Schmidt B, Mayr M, Suzuki K, Xu Q, Ye S. Functional role of matrix metalloproteinase- 8 in stem/progenitor cell migration and their recruitment into atherosclerotic lesions. Circulation research 2013;112:35-47.

44. Xiao Q, Zeng L, Zhang Z, Hu Y, Xu Q. Stem cell-derived Sca-1+ progenitors 
differentiate into smooth muscle cells, which is mediated by collagen IV-integrin alpha1/beta1/alphav and PDGF receptor pathways. American journal of physiology Cell physiology 2007;292:C342-352.

45. Shi N, Chen SY. Smooth Muscle Cell Differentiation: Model Systems, Regulatory Mechanisms, and Vascular Diseases. J Cell Physiol 2016;231:777-787.

46. Mack CP. Signaling mechanisms that regulate smooth muscle cell differentiation. Arteriosclerosis, thrombosis, and vascular biology 2011;31:1495-1505.

47. Xie C, Ritchie RP, Huang H, Zhang J, Chen YE. Smooth muscle cell differentiation in vitro: models and underlying molecular mechanisms. Arterioscler Thromb Vasc Biol 2011;31:1485-1494.

48. Maguire EM, Xiao Q, Xu Q. Differentiation and Application of Induced Pluripotent Stem Cell-Derived Vascular Smooth Muscle Cells. Arterioscler Thromb Vasc Biol 2017;37:2026-2037.

49. Luo Z, Wang G, Wang W, Xiao Q, Xu Q. Signalling pathways that regulate endothelial differentiation from stem cells. Front Biosci (Landmark Ed) 2011;16:472485.

50. Maguire EM, Xiao Q. Noncoding RNAs in vascular smooth muscle cell function and neointimal hyperplasia. The FEBS journal 2020.

51. Zhou Y, Yan H, Guo M, Zhu J, Xiao Q, Zhang L. Reactive oxygen species in vascular formation and development. Oxid Med Cell Longev 2013;2013:374963.

52. Kane NM, Xiao Q, Baker AH, Luo Z, Xu Q, Emanueli C. Pluripotent stem cell differentiation into vascular cells: a novel technology with promises for vascular re(generation). Pharmacology \& therapeutics 2011;129:29-49.

53. Xiao Q, Wang G, Luo Z, Xu Q. The mechanism of stem cell differentiation into smooth muscle cells. Thrombosis and haemostasis 2010;104:440-448.

54. Siebel C, Lendahl U. Notch Signaling in Development, Tissue Homeostasis, and Disease. Physiol Rev 2017;97:1235-1294.

55. Henshall TL, Keller A, He L, Johansson BR, Wallgard E, Raschperger E, Mae MA, Jin $\mathrm{S}$, Betsholtz C, Lendahl U. Notch3 is necessary for blood vessel integrity in the central nervous system. Arterioscler Thromb Vasc Biol 2015;35:409-420.

56. Volz KS, Jacobs AH, Chen HI, Poduri A, McKay AS, Riordan DP, Kofler N, Kitajewski J, Weissman I, Red-Horse K. Pericytes are progenitors for coronary artery smooth muscle. Elife 2015;4. 
57. Wang Q, Zhao N, Kennard S, Lilly B. Notch2 and Notch3 function together to regulate vascular smooth muscle development. PLoS One 2012;7:e37365.

58. Wang Y, Pan L, Moens CB, Appel B. Notch3 establishes brain vascular integrity by regulating pericyte number. Development 2014;141:307-317.

59. Ando K, Wang W, Peng D, Chiba A, Lagendijk AK, Barske L, Crump JG, Stainier DYR, Lendahl U, Koltowska K, Hogan BM, Fukuhara S, Mochizuki N, Betsholtz C. Peri-arterial specification of vascular mural cells from naive mesenchyme requires Notch signaling. Development 2019;146.

60. Benedito R, Roca C, Sorensen I, Adams S, Gossler A, Fruttiger M, Adams RH. The notch ligands DIl4 and Jagged1 have opposing effects on angiogenesis. Cell 2009;137:1124-1135.

61. Cappellari O, Benedetti S, Innocenzi A, Tedesco FS, Moreno-Fortuny A, Ugarte G, Lampugnani MG, Messina G, Cossu G. DII4 and PDGF-BB convert committed skeletal myoblasts to pericytes without erasing their myogenic memory. Dev Cell 2013;24:586599.

62. Ong CT, Cheng HT, Chang LW, Ohtsuka T, Kageyama R, Stormo GD, Kopan R. Target selectivity of vertebrate notch proteins. Collaboration between discrete domains and CSL-binding site architecture determines activation probability. The Journal of biological chemistry 2006;281:5106-5119.

63. Li Y, Takeshita K, Liu PY, Satoh M, Oyama N, Mukai Y, Chin MT, Krebs L, Kotlikoff MI, Radtke F, Gridley T, Liao JK. Smooth muscle Notch1 mediates neointimal formation after vascular injury. Circulation 2009;119:2686-2692.

64. Zhang C, Chen D, Maguire EM, He S, Chen J, An W, Yang M, Afzal TA, Luong LA, Zhang L, Lei $\mathrm{H}$, Wu $\mathrm{Q}$, Xiao $\mathrm{Q}$. Cbx3 inhibits vascular smooth muscle cell proliferation, migration, and neointima formation. Cardiovascular research 2018;114:443-455.

65. Chen Q, Yang F, Guo M, Wen G, Zhang C, Luong le A, Zhu J, Xiao Q, Zhang L. miRNA34a reduces neointima formation through inhibiting smooth muscle cell proliferation and migration. Journal of molecular and cellular cardiology 2015;89:75-86.

66. Burgy $O$, Königshoff $M$. The WNT signaling pathways in wound healing and fibrosis. Matrix Biol 2018;68-69:67-80.

67. Meyer IS, Leuschner F. The role of Wnt signaling in the healing myocardium: a focus on cell specificity. Basic Res Cardiol 2018;113:44.

68. Tam PP, Loebel DA. Gene function in mouse embryogenesis: get set for gastrulation. Nat Rev Genet 2007;8:368-381. 
69. Kimelman D. Mesoderm induction: from caps to chips. Nat Rev Genet 2006;7:360372.

70. Hübner K, Grassme KS, Rao J, Wenke NK, Zimmer CL, Korte L, Müller K, Sumanas S, Greber B, Herzog W. Wnt signaling positively regulates endothelial cell fate specification in the Fli1a-positive progenitor population via Lef1. Dev Biol 2017;430:142-155.

71. Lawson ND, Vogel AM, Weinstein BM. sonic hedgehog and vascular endothelial growth factor act upstream of the Notch pathway during arterial endothelial differentiation. Dev Cell 2002;3:127-136.

72. Lawson ND, Scheer N, Pham VN, Kim CH, Chitnis AB, Campos-Ortega JA, Weinstein $B M$. Notch signaling is required for arterial-venous differentiation during embryonic vascular development. Development 2001;128:3675-3683.

73. Kume T. Specification of arterial, venous, and lymphatic endothelial cells during embryonic development. Histol Histopathol 2010;25:637-646.

74. Lawson ND, Weinstein BM. Arteries and veins: making a difference with zebrafish. Nat Rev Genet 2002;3:674-682.

75. Weinstein BM, Lawson ND. Arteries, veins, Notch, and VEGF. Cold Spring Harb Symp Quant Biol 2002;67:155-162.

76. Wang X, Hu G, Gao X, Wang Y, Zhang W, Harmon EY, Zhi X, Xu Z, Lennartz MR, Barroso $M$, Trebak $M$, Chen $C$, Zhou J. The induction of yes-associated protein expression after arterial injury is crucial for smooth muscle phenotypic modulation and neointima formation. Arterioscler Thromb Vasc Biol 2012;32:2662-2669.

77. Cho H, Kim J, Ahn JH, Hong YK, Makinen T, Lim DS, Koh GY. YAP and TAZ Negatively Regulate Prox1 During Developmental and Pathologic Lymphangiogenesis. Circulation research 2019;124:225-242.

78. Grimm L, Nakajima H, Chaudhury S, Bower NI, Okuda KS, Cox AG, Harvey NL, Koltowska K, Mochizuki N, Hogan BM. Yap1 promotes sprouting and proliferation of lymphatic progenitors downstream of Vegfc in the zebrafish trunk. eLife 2019;8.

79. Wang X, Freire Valls A, Schermann G, Shen Y, Moya IM, Castro L, Urban S, Solecki GM, Winkler F, Riedemann L, Jain RK, Mazzone M, Schmidt T, Fischer T, Halder G, Ruiz de Almodovar C. YAP/TAZ Orchestrate VEGF Signaling during Developmental Angiogenesis. Developmental cell 2017;42:462-478 e467.

80. Manderfield LJ, Aghajanian H, Engleka KA, Lim LY, Liu F, Jain R, Li L, Olson EN, Epstein JA. Hippo signaling is required for Notch-dependent smooth muscle 
differentiation of neural crest. Development 2015;142:2962-2971.

81. Singh A, Ramesh S, Cibi DM, Yun LS, Li J, Li L, Manderfield LJ, Olson EN, Epstein JA, Singh MK. Hippo Signaling Mediators Yap and Taz Are Required in the Epicardium for Coronary Vasculature Development. Cell reports 2016;15:1384-1393.

82. Andersen $\mathrm{P}$, Uosaki $\mathrm{H}$, Shenje $\mathrm{LT}$, Kwon $\mathrm{C}$. Non-canonical Notch signaling: emerging role and mechanism. Trends Cell Biol 2012;22:257-265.

83. Ayaz F, Osborne BA. Non-canonical notch signaling in cancer and immunity. Front Oncol 2014;4:345.

84. Martinez Arias A, Zecchini V, Brennan K. CSL-independent Notch signalling: a checkpoint in cell fate decisions during development? Current opinion in genetics \& development 2002;12:524-533.

85. Sanalkumar R, Dhanesh SB, James J. Non-canonical activation of Notch signaling/target genes in vertebrates. Cellular and molecular life sciences : CMLS 2010;67:2957-2968.

86. Kwon C, Cheng P, King IN, Andersen P, Shenje L, Nigam V, Srivastava D. Notch posttranslationally regulates beta-catenin protein in stem and progenitor cells. Nature cell biology 2011;13:1244-1251.

87. Liu Z, Sneve M, Haroldson TA, Smith JP, Drewes LR. Regulation of Monocarboxylic Acid Transporter 1 Trafficking by the Canonical Wnt/ $\beta$-Catenin Pathway in Rat Brain Endothelial Cells Requires Cross-talk with Notch Signaling. J Biol Chem 2016;291:80598069.

88. Conte MS. Critical appraisal of surgical revascularization for critical limb ischemia. J Vasc Surg 2013;57:8s-13s.

89. Pashneh-Tala S, MacNeil S, Claeyssens F. The Tissue-Engineered Vascular GraftPast, Present, and Future. Tissue Eng Part B Rev 2016;22:68-100.

90. Matsuzaki Y, John K, Shoji T, Shinoka T. The Evolution of Tissue Engineered Vascular Graft Technologies: From Preclinical Trials to Advancing Patient Care. Appl Sci (Basel) 2019;9.

91. Manikowski D, Andrée B, Samper E, Saint-Marc C, Olmer R, Vogt P, Strauß S, Haverich A, Hilfiker A. Human adipose tissue-derived stromal cells in combination with exogenous stimuli facilitate three-dimensional network formation of human endothelial cells derived from various sources. Vascul Pharmacol 2018;106:28-36.

92. McIntosh K, Zvonic S, Garrett S, Mitchell JB, Floyd ZE, Hammill L, Kloster A, Di 
Halvorsen Y, Ting JP, Storms RW, Goh B, Kilroy G, Wu X, Gimble JM. The immunogenicity of human adipose-derived cells: temporal changes in vitro. Stem Cells 2006;24:12461253.

93. Collado MS, Cole BK, Figler RA, Lawson M, Manka D, Simmers MB, Hoang S, Serrano F, Blackman BR, Sinha S, Wamhoff BR. Exposure of Induced Pluripotent Stem Cell-Derived Vascular Endothelial and Smooth Muscle Cells in Coculture to Hemodynamics Induces Primary Vascular Cell-Like Phenotypes. Stem Cells Transl Med 2017;6:1673-1683.

94. Luo J, Qin L, Zhao L, Gui L, Ellis MW, Huang Y, Kural MH, Clark JA, Ono S, Wang J, Yuan Y, Zhang SM, Cong X, Li G, Riaz M, Lopez C, Hotta A, Campbell S, Tellides G, Dardik A, Niklason LE, Qyang Y. Tissue-Engineered Vascular Grafts with Advanced Mechanical Strength from Human iPSCs. Cell Stem Cell 2020;26:251-261.e258.

95. Arck PC, Hecher K. Fetomaternal immune cross-talk and its consequences for maternal and offspring's health. Nature medicine 2013;19:548-556.

96. Deuse T, Hu X, Gravina A, Wang D, Tediashvili G, De C, Thayer WO, Wahl A, Garcia JV, Reichenspurner H, Davis MM, Lanier LL, Schrepfer S. Hypoimmunogenic derivatives of induced pluripotent stem cells evade immune rejection in fully immunocompetent allogeneic recipients. Nat Biotechnol 2019;37:252-258.

97. Jaiswal S, Jamieson CH, Pang WW, Park CY, Chao MP, Majeti R, Traver D, van Rooijen N, Weissman IL. CD47 is upregulated on circulating hematopoietic stem cells and leukemia cells to avoid phagocytosis. Cell 2009;138:271-285.

98. Chang $\mathrm{CH}$, Fontes JD, Peterlin M, Flavell RA. Class II transactivator (CIITA) is sufficient for the inducible expression of major histocompatibility complex class II genes. J Exp Med 1994;180:1367-1374.

99. Rossant J. Gene editing in human development: ethical concerns and practical applications. Development 2018;145.

100. Peris-Torres C, Serrano O, Plaza-Calonge MDC, Rodriguez-Manzaneque JC. Inhibition of ADAMTS1 Expression by Lentiviral CRISPR/Cas9 Gene Editing Technology. Methods Mol Biol 2020;2043:13-24.

101. Doetschman T, Georgieva T. Gene Editing With CRISPR/Cas9 RNA-Directed Nuclease. Circ Res 2017;120:876-894.

102. Crist AM, Young C, Meadows SM. Characterization of arteriovenous identity in the developing neonate mouse retina. Gene Expr Patterns 2017;23-24:22-31.

103. Fatehullah A, Tan SH, Barker N. Organoids as an in vitro model of human 
development and disease. Nat Cell Biol 2016;18:246-254.

104. Lang SH, Sharrard RM, Stark M, Villette JM, Maitland NJ. Prostate epithelial cell lines form spheroids with evidence of glandular differentiation in threedimensional Matrigel cultures. Br J Cancer 2001;85:590-599.

105. Huch $M$, Gehart $H$, van Boxtel R, Hamer K, Blokzijl F, Verstegen MM, Ellis E, van Wenum M, Fuchs SA, de Ligt J, van de Wetering M, Sasaki N, Boers SJ, Kemperman $\mathrm{H}$, de Jonge J, Ijzermans JN, Nieuwenhuis EE, Hoekstra R, Strom S, Vries RR, van der Laan L, Cuppen E, Clevers H. Long-term culture of genome-stable bipotent stem cells from adult human liver. Cell 2015;160:299-312.

106. Wang S, Wang X, Tan Z, Su Y, Liu J, Chang M, Yan F, Chen J, Chen T, Li C, Hu J, Wang $Y$. Human ESC-derived expandable hepatic organoids enable therapeutic liver repopulation and pathophysiological modeling of alcoholic liver injury. Cell Res 2019;29:1009-1026.

107. Dye BR, Hill DR, Ferguson MA, Tsai YH, Nagy MS, Dyal R, Wells JM, Mayhew CN, Nattiv R, Klein OD, White ES, Deutsch GH, Spence JR. In vitro generation of human pluripotent stem cell derived lung organoids. Elife 2015;4.

108. Drost J, Karthaus WR, Gao D, Driehuis E, Sawyers CL, Chen Y, Clevers H. Organoid culture systems for prostate epithelial and cancer tissue. Nat Protoc 2016;11:347-358.

109. Vlachogiannis G, Hedayat S, Vatsiou A, Jamin Y, Fernandez-Mateos J, Khan K, Lampis A, Eason K, Huntingford I, Burke R, Rata M, Koh DM, Tunariu N, Collins D, HulkkiWilson S, Ragulan C, Spiteri I, Moorcraft SY, Chau I, Rao S, Watkins D, Fotiadis N, Bali M, Darvish-Damavandi M, Lote H, Eltahir Z, Smyth EC, Begum R, Clarke PA, Hahne JC, Dowsett M, de Bono J, Workman P, Sadanandam A, Fassan M, Sansom OJ, Eccles S, Starling N, Braconi C, Sottoriva A, Robinson SP, Cunningham D, Valeri N. Patient-derived organoids model treatment response of metastatic gastrointestinal cancers. Science 2018;359:920-926.

110. McCracken KW, Cata EM, Crawford CM, Sinagoga KL, Schumacher M, Rockich BE, Tsai YH, Mayhew CN, Spence JR, Zavros Y, Wells JM. Modelling human development and disease in pluripotent stem-cell-derived gastric organoids. Nature 2014;516:400404.

111. Lancaster MA, Renner M, Martin CA, Wenzel D, Bicknell LS, Hurles ME, Homfray T, Penninger JM, Jackson AP, Knoblich JA. Cerebral organoids model human brain development and microcephaly. Nature 2013;501:373-379.

112. Dang J, Tiwari SK, Lichinchi G, Qin Y, Patil VS, Eroshkin AM, Rana TM. Zika Virus 
Depletes Neural Progenitors in Human Cerebral Organoids through Activation of the Innate Immune Receptor TLR3. Cell Stem Cell 2016;19:258-265.

113. Dekkers JF, Berkers G, Kruisselbrink E, Vonk A, de Jonge HR, Janssens HM, Bronsveld I, van de Graaf EA, Nieuwenhuis EE, Houwen RH, Vleggaar FP, Escher JC, de Rijke YB, Majoor CJ, Heijerman HG, de Winter-de Groot KM, Clevers H, van der Ent CK, Beekman JM. Characterizing responses to CFTR-modulating drugs using rectal organoids derived from subjects with cystic fibrosis. Sci Transl Med 2016;8:344ra384.

114. Vives J, Batlle-Morera L. The challenge of developing human 3D organoids into medicines. Stem Cell Res Ther, 2020:72.

115. Yui S, Nakamura T, Sato T, Nemoto Y, Mizutani T, Zheng X, Ichinose S, Nagaishi T, Okamoto R, Tsuchiya K, Clevers $\mathrm{H}$, Watanabe M. Functional engraftment of colon epithelium expanded in vitro from a single adult Lgr5(+) stem cell. Nat Med 2012;18:618-623.

116. Daviaud N, Friedel RH, Zou $\mathrm{H}$. Vascularization and Engraftment of Transplanted Human Cerebral Organoids in Mouse Cortex. eNeuro 2018;5.

117. Hu H, Gehart H, Artegiani B, C LO-I, Dekkers F, Basak O, van Es J, Chuva de Sousa Lopes SM, Begthel H, Korving J, van den Born M, Zou C, Quirk C, Chiriboga L, Rice CM, Ma S, Rios A, Peters PJ, de Jong YP, Clevers H. Long-Term Expansion of Functional Mouse and Human Hepatocytes as 3D Organoids. Cell 2018;175:15911606.e1519.

118. Goldie LC, Nix MK, Hirschi KK. Embryonic vasculogenesis and hematopoietic specification. Organogenesis 2008;4:257-263.

119. Finnemore A, Groves A. Physiology of the fetal and transitional circulation. Semin Fetal Neonatal Med 2015;20:210-216.

120. Adams RH, Alitalo K. Molecular regulation of angiogenesis and lymphangiogenesis. Nat Rev Mol Cell Biol 2007;8:464-478.

121. Carmeliet P. Mechanisms of angiogenesis and arteriogenesis. Nat Med 2000;6:389-395.

122. Song HG, Rumma RT, Ozaki CK, Edelman ER, Chen CS. Vascular Tissue Engineering: Progress, Challenges, and Clinical Promise. Cell Stem Cell 2018;22:340354.

123. Wimmer RA, Leopoldi A, Aichinger M, Kerjaschki D, Penninger JM. Generation of blood vessel organoids from human pluripotent stem cells. Nat Protoc 2019;14:3082-3100. 
124. Huch M, Knoblich JA, Lutolf MP, Martinez-Arias A. The hope and the hype of organoid research. Development 2017;144:938-941.

125. Phipson B, Er PX, Combes AN, Forbes TA, Howden SE, Zappia L, Yen HJ, Lawlor KT, Hale LJ, Sun J, Wolvetang E, Takasato M, Oshlack A, Little MH. Evaluation of variability in human kidney organoids. Nat Methods 2019;16:79-87.

126. Damani SB, Topol EJ. Emerging genomic applications in coronary artery disease. JACC Cardiovasc Interv 2011;4:473-482.

127. Grebenyuk S, Ranga A. Engineering Organoid Vascularization. Front Bioeng Biotechnol 2019;7:39.

128. Pham MT, Pollock KM, Rose MD, Cary WA, Stewart HR, Zhou P, Nolta JA, Waldau B. Generation of human vascularized brain organoids. Neuroreport 2018;29:588-593.

129. Lancaster MA, Knoblich JA. Generation of cerebral organoids from human pluripotent stem cells. Nat Protoc 2014;9:2329-2340.

130. Mansour AA, Goncalves JT, Bloyd CW, Li H, Fernandes S, Quang D, Johnston S, Parylak SL, Jin X, Gage FH. An in vivo model of functional and vascularized human brain organoids. Nat Biotechnol 2018;36:432-441.

131. Wörsdörfer P, Dalda N, Kern A, Krüger S, Wagner N, Kwok CK, Henke E, Ergün S. Generation of complex human organoid models including vascular networks by incorporation of mesodermal progenitor cells. Sci Rep 2019;9:15663.

132. Straub AC, Zeigler AC, Isakson BE. The myoendothelial junction: connections that deliver the message. Physiology (Bethesda) 2014;29:242-249.

133. Lee S, Kim JE, Johnson BA, Andukuri A, Yoon YS. Direct reprogramming into endothelial cells: a new source for vascular regeneration. Regen Med 2017;12:317-320.

134. Cakir B, Xiang Y, Tanaka Y, Kural MH, Parent M, Kang YJ, Chapeton K, Patterson B, Yuan Y, He CS, Raredon MSB, Dengelegi J, Kim KY, Sun P, Zhong M, Lee S, Patra P, Hyder F, Niklason LE, Lee SH, Yoon YS, Park IH. Engineering of human brain organoids with a functional vascular-like system. Nat Methods 2019;16:1169-1175.

135. Orsi NM, Reischl JB. Mammalian embryo co-culture: trials and tribulations of a misunderstood method. Theriogenology 2007;67:441-458.

136. Ham O, Jin YB, Kim J, Lee MO. Blood vessel formation in cerebral organoids formed from human embryonic stem cells. Biochem Biophys Res Commun 2020;521:84-90. 
137. Taguchi A, Kaku Y, Ohmori T, Sharmin S, Ogawa M, Sasaki H, Nishinakamura R. Redefining the in vivo origin of metanephric nephron progenitors enables generation of complex kidney structures from pluripotent stem cells. Cell Stem Cell 2014;14:5367.

138. Morizane R, Lam AQ, Freedman BS, Kishi S, Valerius MT, Bonventre JV. Nephron organoids derived from human pluripotent stem cells model kidney development and injury. Nat Biotechnol 2015;33:1193-1200.

139. Freedman BS, Brooks CR, Lam AQ, Fu H, Morizane R, Agrawal V, Saad AF, Li MK, Hughes MR, Werff RV, Peters DT, Lu J, Baccei A, Siedlecki AM, Valerius MT, Musunuru K, McNagny KM, Steinman TI, Zhou J, Lerou PH, Bonventre JV. Modelling kidney disease with CRISPR-mutant kidney organoids derived from human pluripotent epiblast spheroids. Nat Commun 2015;6:8715.

140. van den Berg CW, Ritsma L, Avramut MC, Wiersma LE, van den Berg BM, Leuning DG, Lievers E, Koning M, Vanslambrouck JM, Koster AJ, Howden SE, Takasato M, Little MH, Rabelink TJ. Renal Subcapsular Transplantation of PSC-Derived Kidney Organoids Induces Neo-vasculogenesis and Significant Glomerular and Tubular Maturation In Vivo. Stem Cell Reports 2018;10:751-765.

141. Homan KA, Gupta N, Kroll KT, Kolesky DB, Skylar-Scott M, Miyoshi T, Mau D, Valerius MT, Ferrante T, Bonventre JV, Lewis JA, Morizane R. Flow-enhanced vascularization and maturation of kidney organoids in vitro. Nat Methods 2019;16:255-262.

142. Morizane R, Bonventre JV. Generation of nephron progenitor cells and kidney organoids from human pluripotent stem cells. Nat Protoc 2017;12:195-207.

143. Low JH, Li P, Chew EGY, Zhou B, Suzuki K, Zhang T, Lian MM, Liu M, Aizawa E, Rodriguez Esteban C, Yong KSM, Chen Q, Campistol JM, Fang M, Khor CC, Foo JN, Izpisua Belmonte JC, Xia Y. Generation of Human PSC-Derived Kidney Organoids with Patterned Nephron Segments and a De Novo Vascular Network. Cell Stem Cell 2019;25:373-387.e379.

144. Holloway EM, Capeling MM, Spence JR. Biologically inspired approaches to enhance human organoid complexity. Development 2019;146.

145. Ma Z, Wang J, Loskill P, Huebsch N, Koo S, Svedlund FL, Marks NC, Hua EW, Grigoropoulos CP, Conklin BR, Healy KE. Self-organizing human cardiac microchambers mediated by geometric confinement. Nat Commun 2015;6:7413.

146. Mills RJ, Titmarsh DM, Koenig X, Parker BL, Ryall JG, Quaife-Ryan GA, Voges HK, Hodson MP, Ferguson C, Drowley L, Plowright AT, Needham EJ, Wang QD, 
Gregorevic P, Xin M, Thomas WG, Parton RG, Nielsen LK, Launikonis BS, James DE, Elliott DA, Porrello ER, Hudson JE. Functional screening in human cardiac organoids reveals a metabolic mechanism for cardiomyocyte cell cycle arrest. Proc Natl Acad Sci U S A 2017;114:E8372-e8381.

147. Richards DJ, Coyle RC, Tan Y, Jia J, Wong K, Toomer K, Menick DR, Mei Y. Inspiration from heart development: Biomimetic development of functional human cardiac organoids. Biomaterials 2017;142:112-123.

148. Zhang YS, Arneri A, Bersini S, Shin SR, Zhu K, Goli-Malekabadi Z, Aleman J, Colosi C, Busignani F, Dell'Erba V, Bishop C, Shupe T, Demarchi D, Moretti M, Rasponi M, Dokmeci MR, Atala A, Khademhosseini A. Bioprinting 3D microfibrous scaffolds for engineering endothelialized myocardium and heart-on-a-chip. Biomaterials 2016;110:45-59.

149. Mills RJ, Parker BL, Quaife-Ryan GA, Voges HK, Needham EJ, Bornot A, Ding M, Andersson H, Polla M, Elliott DA, Drowley L, Clausen M, Plowright AT, Barrett IP, Wang QD, James DE, Porrello ER, Hudson JE. Drug Screening in Human PSC-Cardiac Organoids Identifies Pro-proliferative Compounds Acting via the Mevalonate Pathway. Cell stem cell 2019;24:895-907 e896.

150. Takebe T, Sekine K, Enomura M, Koike H, Kimura M, Ogaeri T, Zhang RR, Ueno Y, Zheng YW, Koike N, Aoyama S, Adachi Y, Taniguchi H. Vascularized and functional human liver from an iPSC-derived organ bud transplant. Nature 2013;499:481-484.

151. Pettinato G, Lehoux S, Ramanathan R, Salem MM, He LX, Muse O, Flaumenhaft R, Thompson MT, Rouse EA, Cummings RD, Wen X, Fisher RA. Generation of fully functional hepatocyte-like organoids from human induced pluripotent stem cells mixed with Endothelial Cells. Sci Rep 2019;9:8920.

152. Takebe T, Sekine K, Kimura M, Yoshizawa E, Ayano S, Koido M, Funayama S, Nakanishi N, Hisai T, Kobayashi T, Kasai T, Kitada R, Mori A, Ayabe H, Ejiri Y, Amimoto N, Yamazaki Y, Ogawa S, Ishikawa M, Kiyota Y, Sato Y, Nozawa K, Okamoto S, Ueno Y, Taniguchi H. Massive and Reproducible Production of Liver Buds Entirely from Human Pluripotent Stem Cells. Cell Rep 2017;21:2661-2670.

153. Koui Y, Kido T, Ito T, Oyama H, Chen SW, Katou Y, Shirahige K, Miyajima A. An In Vitro Human Liver Model by iPSC-Derived Parenchymal and Non-parenchymal Cells. Stem Cell Reports 2017;9:490-498.

154. Goulart E, de Caires-Junior LC, Telles-Silva KA, Araujo BHS, Kobayashi GS, Musso CM, Assoni AF, Oliveira D, Caldini E, Gerstenhaber JA, Raia S, Lelkes PI, Zatz M. Adult and iPS-derived non-parenchymal cells regulate liver organoid development through differential modulation of Wnt and TGF- $\beta$. Stem Cell Res Ther 2019;10:258. 
155. Vargas-Valderrama A, Messina A, Mitjavila-Garcia MT, Guenou H. The endothelium, a key actor in organ development and hPSC-derived organoid vascularization. J Biomed Sci 2020;27:67.

156. Dye BR, Dedhia PH, Miller AJ, Nagy MS, White ES, Shea LD, Spence JR. A bioengineered niche promotes in vivo engraftment and maturation of pluripotent stem cell derived human lung organoids. Elife 2016;5.

157. Takahashi Y, Takebe T, Taniguchi H. Methods for Generating Vascularized IsletLike Organoids Via Self-Condensation. Curr Protoc Stem Cell Biol 2018;45:e49.

158. Candiello J, Grandhi TSP, Goh SK, Vaidya V, Lemmon-Kishi M, Eliato KR, Ros R, Kumta PN, Rege K, Banerjee I. 3D heterogeneous islet organoid generation from human embryonic stem cells using a novel engineered hydrogel platform. Biomaterials 2018;177:27-39.

159. Spence JR, Mayhew CN, Rankin SA, Kuhar MF, Vallance JE, Tolle K, Hoskins EE, Kalinichenko VV, Wells SI, Zorn AM, Shroyer NF, Wells JM. Directed differentiation of human pluripotent stem cells into intestinal tissue in vitro. Nature 2011;470:105-109.

160. Watson CL, Mahe MM, Múnera J, Howell JC, Sundaram N, Poling HM, Schweitzer JI, Vallance JE, Mayhew CN, Sun Y, Grabowski G, Finkbeiner SR, Spence JR, Shroyer NF, Wells JM, Helmrath MA. An in vivo model of human small intestine using pluripotent stem cells. Nat Med 2014;20:1310-1314.

161. Tsilibary EC. Microvascular basement membranes in diabetes mellitus. J Pathol 2003;200:537-546.

162. Zheng X, Narayanan S, Sunkari VG, Eliasson S, Botusan IR, Grünler J, Catrina Al, Radtke F, Xu C, Zhao A, Ekberg NR, LendahI U, Catrina SB. Triggering of a Dll4-Notch1 loop impairs wound healing in diabetes. Proc Natl Acad Sci U S A 2019;116:6985-6994.

163. Liu H, Zhang W, Lilly B. Evaluation of Notch3 Deficiency in Diabetes-Induced Pericyte Loss in the Retina. J Vasc Res 2018;55:308-318.

164. Carmeliet P, Jain RK. Molecular mechanisms and clinical applications of angiogenesis. Nature 2011;473:298-307.

165. Carmeliet P. Angiogenesis in health and disease. Nat Med 2003;9:653-660.

166. Park HJ, Zhang Y, Georgescu SP, Johnson KL, Kong D, Galper JB. Human umbilical vein endothelial cells and human dermal microvascular endothelial cells offer new insights into the relationship between lipid metabolism and angiogenesis. Stem Cell Rev 2006;2:93-102. 
167. Rak-Raszewska A, Hauser PV, Vainio S. Organ In Vitro Culture: What Have We Learned about Early Kidney Development? Stem Cells Int 2015;2015:959807.

168. Campisi M, Shin Y, Osaki T, Hajal C, Chiono V, Kamm RD. 3D self-organized microvascular model of the human blood-brain barrier with endothelial cells, pericytes and astrocytes. Biomaterials 2018;180:117-129.

169. Menon NV, Tay HM, Wee SN, Li KHH, Hou HW. Micro-engineered perfusable 3D vasculatures for cardiovascular diseases. Lab Chip 2017;17:2960-2968.

170. Lin NYC, Homan KA, Robinson SS, Kolesky DB, Duarte N, Moisan A, Lewis JA. Renal reabsorption in 3D vascularized proximal tubule models. Proc Natl Acad Sci U S A 2019;116:5399-5404.

171. Hoeben A, Landuyt B, Highley MS, Wildiers H, Van Oosterom AT, De Bruijn EA. Vascular endothelial growth factor and angiogenesis. Pharmacol Rev 2004;56:549-580.

172. Cyron CJ, Humphrey JD. Vascular homeostasis and the concept of mechanobiological stability. Int J Eng Sci 2014;85:203-223.

173. Noonan J, Grassia G, MacRitchie N, Garside P, Guzik TJ, Bradshaw AC, Maffia P. A Novel Triple-Cell Two-Dimensional Model to Study Immune-Vascular Interplay in Atherosclerosis. Front Immunol 2019;10:849.

174. Pettinato G, Wen X, Zhang N. Formation of well-defined embryoid bodies from dissociated human induced pluripotent stem cells using microfabricated cellrepellent microwell arrays. Sci Rep 2014;4:7402.

175. Pinto AR, llinykh A, Ivey MJ, Kuwabara JT, D'Antoni ML, Debuque R, Chandran A, Wang L, Arora K, Rosenthal NA, Tallquist MD. Revisiting Cardiac Cellular Composition. Circ Res 2016;118:400-409.

176. Devalla HD, Passier R. Cardiac differentiation of pluripotent stem cells and implications for modeling the heart in health and disease. Sci Trans/ Med 2018;10.

177. Kopan R, llagan MX. The canonical Notch signaling pathway: unfolding the activation mechanism. Cell 2009;137:216-233.

178. Tsunematsu R, Nakayama K, Oike Y, Nishiyama M, Ishida N, Hatakeyama S, Bessho Y, Kageyama R, Suda T, Nakayama KI. Mouse Fbw7/Sel-10/Cdc4 is required for notch degradation during vascular development. J Biol Chem 2004;279:9417-9423.

179. Daud M, Rana MA, Husnain T, Ijaz B. Modulation of Wnt signaling pathway by hepatitis B virus. Arch Virol 2017;162:2937-2947. 
180. Komiya $\mathrm{Y}$, Habas R. Wnt signal transduction pathways. Organogenesis 2008;4:68-75.

181. Rao TP, Kuhl M. An updated overview on Wnt signaling pathways: a prelude for more. Circulation research 2010;106:1798-1806.

182. Leung JY, Kolligs FT, Wu R, Zhai Y, Kuick R, Hanash S, Cho KR, Fearon ER. Activation of AXIN2 expression by beta-catenin-T cell factor. A feedback repressor pathway regulating Wnt signaling. J Biol Chem 2002;277:21657-21665.

183. Behrens J, Jerchow BA, Würtele $M$, Grimm J, Asbrand C, Wirtz R, Kühl M, Wedlich $D$, Birchmeier W. Functional interaction of an axin homolog, conductin, with beta-catenin, APC, and GSK3beta. Science 1998;280:596-599.

184. Kim KA, Zhao J, Andarmani S, Kakitani M, Oshima T, Binnerts ME, Abo A, Tomizuka K, Funk WD. R-Spondin proteins: a novel link to beta-catenin activation. Cell cycle 2006;5:23-26.

185. Mueller TD, Nickel J. Promiscuity and specificity in BMP receptor activation. FEBS Lett 2012;586:1846-1859.

186. Heldin $\mathrm{CH}$, Miyazono K, ten Dijke P. TGF-beta signalling from cell membrane to nucleus through SMAD proteins. Nature 1997;390:465-471.

187. Huang Z, Wang D, Ihida-Stansbury K, Jones PL, Martin JF. Defective pulmonary vascular remodeling in Smad8 mutant mice. Hum Mol Genet 2009;18:2791-2801.

188. Chan MC, Hilyard AC, Wu C, Davis BN, Hill NS, Lal A, Lieberman J, Lagna G, Hata A. Molecular basis for antagonism between PDGF and the TGFbeta family of signalling pathways by control of miR-24 expression. Embo j 2010;29:559-573.

189. Bai H, Gao Y, Arzigian M, Wojchowski DM, Wu WS, Wang ZZ. BMP4 regulates vascular progenitor development in human embryonic stem cells through a Smaddependent pathway. J Cell Biochem 2010;109:363-374.

190. DiSalvo J, Bayne ML, Conn G, Kwok PW, Trivedi PG, Soderman DD, Palisi TM, Sullivan KA, Thomas KA. Purification and characterization of a naturally occurring vascular endothelial growth factor.placenta growth factor heterodimer. J Biol Chem 1995;270:7717-7723.

191. Pagès G, Pouysségur J. Transcriptional regulation of the Vascular Endothelial Growth Factor gene--a concert of activating factors. Cardiovasc Res 2005;65:564-573.

192. Kappert K, Peters KG, Böhmer FD, Ostman A. Tyrosine phosphatases in vessel wall signaling. Cardiovasc Res 2005;65:587-598. 
193. Bouloumié A, Schini-Kerth VB, Busse R. Vascular endothelial growth factor upregulates nitric oxide synthase expression in endothelial cells. Cardiovasc Res 1999;41:773-780.

194. Nourse MB, Halpin DE, Scatena M, Mortisen DJ, Tulloch NL, Hauch KD, TorokStorb B, Ratner BD, Pabon L, Murry CE. VEGF induces differentiation of functional endothelium from human embryonic stem cells: implications for tissue engineering. Arterioscler Thromb Vasc Biol 2010;30:80-89.

195. Andrae J, Gallini R, Betsholtz C. Role of platelet-derived growth factors in physiology and medicine. Genes Dev 2008;22:1276-1312.

196. Hellström M, Kalén M, Lindahl P, Abramsson A, Betsholtz C. Role of PDGF-B and PDGFR-beta in recruitment of vascular smooth muscle cells and pericytes during embryonic blood vessel formation in the mouse. Development 1999;126:3047-3055.

197. Chaudhary LR, Hruska KA. The cell survival signal Akt is differentially activated by PDGF-BB, EGF, and FGF-2 in osteoblastic cells. J Cell Biochem 2001;81:304-311.

198. Ball SG, Shuttleworth CA, Kielty CM. Mesenchymal stem cells and neovascularization: role of platelet-derived growth factor receptors. I Cell Mol Med 2007;11:1012-1030. 


\begin{tabular}{|c|c|c|c|c|}
\hline $\begin{array}{l}\text { Signalling } \\
\text { pathways }\end{array}$ & $\begin{array}{l}\text { Main } \\
\text { ligands/rece } \\
\text { ptors }\end{array}$ & $\begin{array}{l}\text { Transcriptional } \\
\text { mediator, co- } \\
\text { regulators \& Key } \\
\text { response element }\end{array}$ & $\begin{array}{l}\text { Functions in vascular } \\
\text { cell specification }\end{array}$ & Reference \\
\hline $\begin{array}{l}\text { Canonical } \\
\text { Notch }\end{array}$ & $\begin{array}{l}\text { Ligand: } \\
\text { DII 1, } 3 \text { and 4; } \\
\text { Jagged } 1 \text { and } \\
\text { 2; } \\
\text { Receptor: } \\
\text { Notch1-4 }\end{array}$ & $\begin{array}{l}\text { Mediator: } \\
\text { NICD (degradation of } \\
\text { Notchs by Sel- } \\
\text { 10/Cdc4); } \\
\text { Co-regulator: } \\
\text { RBPJ \& MAML; } \\
\text { Response element } \\
\text { with consensus } \\
\text { sequence of } \\
\text { RTGRGAR (where R } \\
\text { is G or A) }\end{array}$ & $\begin{array}{l}\text { Ligand-receptor type- } \\
\text { dependent effect and } \\
\text { region-specific } \\
\text { distinctions; } \\
\text { Notch3 and Notch2 } \\
\text { predominately regulate } \\
\text { MC development, while } \\
\text { Notch1 and Notch4 } \\
\text { mainly control EC } \\
\text { development and } \\
\text { function }\end{array}$ & $\begin{array}{l}177 ; 178 ; 55 ; 56 ; \\
57\end{array}$ \\
\hline $\begin{array}{l}\text { Canonical } \\
\text { Wnt }\end{array}$ & $\begin{array}{l}\text { Ligand: } \\
\text { Wnt-1, -2, -3, } \\
-3 a,-8 a,-8 b,- \\
\text { 10a, and - } \\
\text { 10b; } \\
\text { Receptor: } \\
\text { Frizzled } \\
\text { family; } \\
\text { Co-receptor: } \\
\text { Lrp5/6 }\end{array}$ & $\begin{array}{l}\beta \text {-catenin: a } \\
\text { transcriptional co- } \\
\text { activator; } \\
\text { Transported between } \\
\text { cytoplasm \& nuclear; } \\
\text { Downregulated by } \\
\text { Axin2, while } \\
\text { upregulated by } \\
\text { extracellular R- } \\
\text { Spondin; } \\
\text { Co-regulator: } \\
\text { TCF/LEF; } \\
\text { Wnt-response } \\
\text { element (WRE: C/T- } \\
\text { C-T-T-T-G-A/T-A/T) }\end{array}$ & $\begin{array}{l}\text { Ligand- and/or cellular } \\
\text { context-dependent } \\
\text { manner: } \\
\text { Maintains stem cell } \\
\text { function \& tissue } \\
\text { homeostasis cell; } \\
\text { Controlling cell fate } \\
\text { commitment, and organ } \\
\text { development; } \\
\text { Facilitates mesoderm } \\
\text { induction when } \\
\text { activated; } \\
\text { Promotes vessel-like } \\
\text { network formation and } \\
\text { increases functional EC } \\
\text { production }\end{array}$ & $\begin{array}{l}179 ; 180,181 ; 66, \\
67 ; 24 ; \quad 70 ; 182, \\
183 ; 184\end{array}$ \\
\hline $\begin{array}{l}\text { TGF- } \beta / \\
\text { BMP } \\
\text { signalling }\end{array}$ & $\begin{array}{l}\text { Ligand: } \\
\text { TGF- } \beta \text { s }\end{array}$ & $\begin{array}{l}\text { Mediator: } \\
\text { Smad-1, -5, -8 }\end{array}$ & $\begin{array}{l}\text { Critical role in vascular } \\
\text { remodelling; } \\
\text { Regulates vascular }\end{array}$ & $\begin{array}{l}185,186,187,18 \\
8,189\end{array}$ \\
\hline
\end{tabular}




\begin{tabular}{|c|c|c|c|c|}
\hline & $\begin{array}{l}\text { BMP-2, -4,-5,- } \\
6,-7,-8,-9,- \\
\text { 10,-12,-13,-- } \\
\text { 14, } \\
\text { Receptor: } \\
\text { TGF- } \beta R I \text { \& II } \\
\text { Specific to } \\
\text { BMPs: } \\
\text { BMPR-1A or } \\
\text { ALK3, BMPR- } \\
\text { 1B or ALK6, } \\
\text { BMPR-2; } \\
\text { Also for } \\
\text { Activins: } \\
\text { ActR-1A or } \\
\text { ALK2, ActR- } \\
\text { 2A, and ActR- } \\
\text { 2B }\end{array}$ & $\begin{array}{l}\text { Co-mediator: } \\
\text { Smad-4 } \\
\text { Smad-1/-5/-8 can } \\
\text { associate with co- } \\
\text { mediator Smd-4 and } \\
\text { form a signalling } \\
\text { complex, which is } \\
\text { translocated into the } \\
\text { nucleus and function } \\
\text { as transcriptional } \\
\text { factor } \\
\text { BMP responsive } \\
\text { element: Smad- } \\
\text { binding element motif } \\
\text { (GTCTG) and GC-rich } \\
\text { boxes (TGGCGCC) }\end{array}$ & $\begin{array}{l}\text { progenitor development } \\
\text { during embryonic } \\
\text { development; } \\
\text { BMP-dependent } \\
\text { vascular } \\
\text { proliferation/differentiati } \\
\text { on is regulated by } \\
\text { Smad-dependent } \\
\text { microRNA processing }\end{array}$ & \\
\hline $\begin{array}{l}\text { VEGF } \\
\text { Signaling }\end{array}$ & $\begin{array}{l}\text { Ligand: } \\
\text { VEGF-A, -B, - } \\
\text { C, -D } \\
\text { PIGF } \\
\text { Receptor: } \\
\text { VEGFR-1, -2, } \\
-3\end{array}$ & $\begin{array}{l}\text { Mediator: } \\
\text { PI3K/Akt/MAPK } \\
\text { Src } \\
\text { PLCY/PKC } \\
\text { Response element: } \\
\text { High-GC domain } \\
\text { 88bp upstream of } \\
\text { transcriptional } \\
\text { initiation site } \\
\text { GGCGGG/GCGGGG } \\
\text { GCG } \\
\text { Receptor dimerization } \\
\text { is triggered by VEGF } \\
\text { ligand binding, then } \\
\text { initiate downstream } \\
\text { cascade via protein } \\
\text { kinase mediators }\end{array}$ & $\begin{array}{l}\text { Promotes nitric oxide } \\
\text { production and } \\
\text { increased vascular } \\
\text { permeability/endothelial } \\
\text { cell survival; } \\
\text { Critical regulator of } \\
\text { angiogenesis in both } \\
\text { adult and foetal } \\
\text { development; } \\
\text { Promotes endothelial } \\
\text { stem cell differentiation } \\
\text { and induce } \\
\text { differentiation of hPSC } \\
\text { to functional } \\
\text { endothelium }\end{array}$ & $\begin{array}{l}49,190,191,192 \\
, 193,194\end{array}$ \\
\hline
\end{tabular}




\begin{tabular}{|c|c|c|c|c|}
\hline $\begin{array}{l}\text { PDGF } \\
\text { Signaling }\end{array}$ & $\begin{array}{l}\text { Ligand: } \\
\text { PDGF-A, -B,- } \\
\text { C,-D } \\
\text { Receptor: } \\
\text { PDGFR-A,-B }\end{array}$ & $\begin{array}{l}\text { Mediator: } \\
\text { PI3K/Akt/MAPK;Src;P } \\
\text { LCY/PKC; } \\
\text { PDGF ligand dimers (- } \\
\text { AA, -BB, AB) exhibits } \\
\text { varied affinities to } \\
\text { different receptor } \\
\text { isoforms } \\
\text { Dimerization of } \\
\text { PDGFR subunits } \\
\text { initiates signal } \\
\text { transduction which is } \\
\text { mediated downstream } \\
\text { protein kinase } \\
\text { cascade }\end{array}$ & $\begin{array}{l}\text { Promotes lineage } \\
\text { specification of MSCs } \\
\text { into mesenchymal } \\
\text { lineages; } \\
\text { Directs differentiation of } \\
\text { MSCs towards vascular } \\
\text { cell fate; } \\
\text { Facilitates recruitment } \\
\text { of VSMCs/pericytes } \\
\text { during embryonic } \\
\text { development; } \\
\text { Promotes VSMC } \\
\text { proliferation and } \\
\text { phenotype switching }\end{array}$ & $\begin{array}{l}195, \\
196,197,198\end{array}$ \\
\hline
\end{tabular}

Table 1. Brief summarization of Notch, Wnt, BMP, VEGF and PDGF signalling pathways and their underlying roles in vascular cell specification and development. Abbreviation: DII, Delta-like; NICD, Notch intracellular domain; Lrp, lipoprotein receptor-related protein; RBPJ, recombination signal sequence-binding protein Jkappa; MAML, Mastermind-like coactivator; TCF/LEF, T-cell factor/lymphoid enhancer factor; MC, mural cell; EC, endothelial cell; MSC, mesenchymal stem cell; VSMC, vascular smooth muscle cells; BMP, bone morphogenetic protein; VEGF, vascular endothelial growth factor; VEGFR, vascular endothelial growth factor receptor; PIGF, placental growth factor; PI3K, phosphotidylinositol-3 kinase; MAPK, mitogenactivated protein kinase; PLCY, phospholipase C gamma; PKC, protein kinase C; PDGF, Platelet-derived growth factor; PDGFR, platelet-derived growth factor receptor. 


\begin{tabular}{|c|c|c|}
\hline $\begin{array}{l}\text { Unresolved issues } \\
\text { over organoids- } \\
\text { based therapies }\end{array}$ & Challenges/Concerns & Further measurements \\
\hline PSC clonal variation & $\begin{array}{l}\text { Huge variabilities were reported in } \\
\text { different PSC-derived organoids } \\
\text { due to the variations existed in the } \\
\text { different PSC lines including } \\
\text { epigenetic profiles, gene/marker } \\
\text { expressions, as well as } \\
\text { unpredictable long-term genomic } \\
\text { destabilities }\end{array}$ & $\begin{array}{l}\text { To generate more PSC lines } \\
\text { from a diverse pool of } \\
\text { genetic/epigenetic } \\
\text { backgrounds, and conduct } \\
\text { long-term in vitro and in vivo } \\
\text { rigorous functional } \\
\text { characterisation of PSC lines } \\
\text { and PSC-derived organoids. } \\
\text { Widely accepted } \\
\text { international guideline and } \\
\text { standardised (well- } \\
\text { characterised) protocols are } \\
\text { urgently required to } \\
\text { circumvent this issue }\end{array}$ \\
\hline $\begin{array}{l}\text { Size and architectural } \\
\text { differences }\end{array}$ & $\begin{array}{l}\text { Organoids are usually much } \\
\text { smaller in size comparing to in vivo } \\
\text { organs, mainly due to the } \\
\text { constraint of culture conditions and } \\
\text { lack of vascularization }\end{array}$ & $\begin{array}{l}\text { Further optimization into the } \\
\text { culture conditions using } \\
\text { novel culture technologies } \\
\text { (e.g., spinning } \\
\text { bioreactors and orbital } \\
\text { shakers) that could } \\
\text { improve oxygenation and } \\
\text { increase nutrient availability } \\
\text { to the organoid center } \\
\text { Incorporation of } \\
\text { vascularization strategies } \\
\text { into organoids }\end{array}$ \\
\hline Reproducibility & $\begin{array}{l}\text { Batch-to-batch variations that may } \\
\text { negatively affect treatment } \\
\text { outcomes and raise safety } \\
\text { concerns }\end{array}$ & $\begin{array}{l}\text { To develop experimental } \\
\text { model systems with high } \\
\text { fidelity, robustness of cell } \\
\text { fate specification, and } \\
\text { precision of self-assembly } \\
\text { into higher-order organoids }\end{array}$ \\
\hline Scalability & $\begin{array}{l}\text { Large-scale production of } \\
\text { functional organoids are still } \\
\text { unachievable in current laboratory } \\
\text { settings }\end{array}$ & $\begin{array}{l}\text { Utilisation of GMP-qualified } \\
\text { PSC lines and products, } \\
\text { standardised and scalable } \\
\text { protocols, as well as step- } \\
\text { wise quality control } \\
\text { measurement }\end{array}$ \\
\hline
\end{tabular}




\begin{tabular}{|c|c|c|}
\hline $\begin{array}{l}\text { Inadequate } \\
\text { morphology/function }\end{array}$ & $\begin{array}{l}\text { Lack of cell-type diversity and } \\
\text { communication leads to } \\
\text { inadequate functional development }\end{array}$ & $\begin{array}{l}\text { More cells (vascular and } \\
\text { non-vascular) and } \\
\text { environmental cues } \\
\text { (haemodynamic response, } \\
\text { hypoxia, nutrients, } \mathrm{PH} \text {, } \\
\text { electrolyte, etc) could be } \\
\text { incorporated into the } \\
\text { experimental } \\
\text { model systems to produce } \\
\text { functional and dynamic } \\
\text { organoids }\end{array}$ \\
\hline $\begin{array}{l}\text { Lack of pre-clinical } \\
\text { validation }\end{array}$ & $\begin{array}{l}\text { Currently, organoid-based pre- } \\
\text { clinical studies are largely } \\
\text { conducted on small animals }\end{array}$ & $\begin{array}{l}\text { Examine the in vivo long- } \\
\text { term patency, compatibility, } \\
\text { and applicability in large } \\
\text { animals with human disease } \\
\text { settings }\end{array}$ \\
\hline $\begin{array}{l}\text { Limited } \\
\text { understanding of cell } \\
\text { types }\end{array}$ & $\begin{array}{l}\text { Cell types in organoid models } \\
\text { were currently validated using } \\
\text { staining for known marker genes, } \\
\text { which need to be more extensively } \\
\text { characterized for it to be } \\
\text { determined if they are truly } \\
\text { reflective of the rich cell diversity } \\
\text { found in the complex human } \\
\text { organs }\end{array}$ & $\begin{array}{l}\text { New technologies such as } \\
\text { single-cell RNA-sequencing } \\
\text { should be used to better } \\
\text { define the molecular } \\
\text { taxonomy of cell types within } \\
\text { organoids }\end{array}$ \\
\hline $\begin{array}{l}\text { Lack of stable } \\
\text { organized elastin }\end{array}$ & $\begin{array}{l}\text { A lack of stable organized elastin } \\
\text { in the vascular organoids is likely } \\
\text { to contribute to poor in vivo } \\
\text { patency and/or vascular rupture }\end{array}$ & $\begin{array}{l}\text { New approaches in } \\
\text { stimulating elastogenesis in } \\
\text { the vascular organoids } \\
\text { should be } \\
\text { developed/incorporated into } \\
\text { the current protocols, such } \\
\text { as promoting de novo } \\
\text { generation of elastic } \\
\text { fibers by SMCs, } \\
\text { incorporating engineered } \\
\text { synthetic elastin into } \\
\text { organiods, and using } \\
\text { decellularized elastin- } \\
\text { containing extracellular } \\
\text { matrix }\end{array}$ \\
\hline
\end{tabular}




\begin{tabular}{|l|l|l|}
\hline $\begin{array}{l}\text { Unknown metabolic } \\
\text { and physiological } \\
\text { processes in } \\
\text { organoids }\end{array}$ & $\begin{array}{l}\text { Current studies are mainly focused } \\
\text { on gene/protein expression, and } \\
\text { have limitations in capturing the } \\
\text { defining features of cellular } \\
\text { identity/properties within organoids }\end{array}$ & $\begin{array}{l}\text { More effective identification } \\
\text { and comparisons of cellular } \\
\text { composition in organoids } \\
\text { using proteomics, epigenetic } \\
\text { profiling, metabolomics, } \\
\text { and electrophysiological } \\
\text { characterization } \\
\text { of cell types in organoids }\end{array}$ \\
\hline $\begin{array}{l}\text { Lack of knowledge } \\
\text { into the interactions } \\
\text { of organoids with } \\
\text { other organs and the } \\
\text { environment }\end{array}$ & $\begin{array}{l}\text { A clear drawback of current } \\
\text { organoid systems is lacking of } \\
\text { interorgan communication. Its } \\
\text { interaction with local and remote } \\
\text { environment remains elusive }\end{array}$ & $\begin{array}{l}\text { More efforts are urgently } \\
\text { required to develop an } \\
\text { 'organoid-on-a-chip' } \\
\text { technology }\end{array}$ \\
\hline
\end{tabular}

Table 2. Potential challenges that hinder the applications of organoid in regenerative medicine. Abbreviation: GMP, good manufacturing practices; SMCs, smooth muscle cells. 


\section{Figure Legend:}

Figure 1. Spatial arrangement of vascular system. Endothelial cells constitute the inner layer of all types of blood vessels, where smooth muscle cells make up the middle layer (except for capillaries). Moreover, the middle layer of veins is thinner than that of arteries. Arterioles and venules are the secondary vessels of arteries and veins, respectively. As for capillaries, pericytes can be readily found just in-between the endothelial cells and basement membrane.

Figure 2. Schematic diagram illustrating the following induction processes: (1) iPSCs can be differentiated into neural crest cells by FGF-2, followed by further differentiation on stiff matrix, with serum-free medium containing TGF- $\beta 1$; differentiated VSMCs were then seeded onto biodegradable scaffold, followed by cyclic stretching to stimulate cell maturation and collagen synthesis; (2) iPSCs were differentiated into mesodermal cells using BMP4 combined with glycogen synthase kinase 3 inhibitor (CHIR99021 or CP21), and then specified into two different fates, VSMCs and VECs, with either PDGF-BB+Activin-A or VEGF+Forskolin; (3) Parallel-plate flow chamber can maintain a consistent shear stress, which alters the cytoskeleton of iPSC and enhanced their differentiation capacities to VECs. Abbreviations: VSMCs, vascular smooth muscle cells; VECs, vascular endothelial cells; iPSCs, induced pluripotent stem cells; FGF-2, basic fibroblast growth factor; BMP4, bone morphogenetic orotein 4; TGF- $\beta 1$, Transforming growth factor beta $1 ;$ PDGF$B B$, platelet-derived growth factor $B B$.

Figure 3. Strategies to manufacture tissue engineered vascular graft (TEVG). A. Co-culture of VECs and hASCs on decellularized small intestinal submucosa: VECs from five different sources (HUVECs, hCECs, hPAECs, iCell-ECs hiPSC-ECs) were co-cultured with hASCs under controlled stimuli (growth factors, 3D hydrogel) in bio-incubator, resulting in spontaneous formation of vascular network via self-organization. Importantly, VECs were surrounded by hASCs as mural cells, forming small caliber lumens within the $3 D$ hydrogel. B. iPSC-derived VSMCs and VECs: Somatic cells can be isolated either from patients themselves or from other healthy individuals and then reprogrammed into hiPSCs. For homologous hiPSCs, gene-editing tool (CRISPR-Cas9) enables acquisition of hypoimmunogenic hiPSCs (B2m-1-/Ciita-/-/Cd47). Afterwards, hiPSC-VSMCs were seeded onto a scaffold with appropriate stiffness and then transferred into bio-incubator, where proper temperature, mechanical stimulation, humidity, $\mathrm{pH}$ and growth factors are 
controlled precisely to generate preliminary TEVG. Thereafter, hiPSC-VECs coated the lumen of preliminary TEVG to create the final TEVG which are ready for vascular grafting. Abbreviations: VSMCs, vascular smooth muscle cells; VECs, vascular endothelial cells; hASCs, human adipose tissue-derived stromal cells; HUVECs, human umbilical vein endothelial cells; hCEC, human cardiac endothelial cell; hPAEC, human pulmonary artery endothelial cell; iCellECs, iPSC derived endothelial cells from Cellular Dynamics International; EC, endothelial cells.

Figure 4 Schematic representation of in vitro generation of hPSC-derived vascular organoids. Using this multi-step protocol as reported by Wimmer et al vascular organoids can be successfully created from hPSCs (human pluripotent stem cells) and maintained in culture dishes, which could be used for pathophysiological study, disease modelling, high-throughput drug screening, and in vivo transplantation, respectively.

Figure 5. A diagrammatic representation of the original and vascularized whole-brain organoid protocols reported by a) Lancaster et al. 2014 as well as recently developed strategies of vascularization of human whole-brain organoids by b) Pham et al. 2018, c) Wörsdörfer et al. 2019, d) Cakir et al. 2019, and e) Ham et al. 2020).

Figure 6 Applications of in vitro vascular organotypic technology. A. Pluriopotent Stem Cell-derived vascular organoids may provide new insights into pivotal developmental events or signalling pathways during organogenesis. B. Patient-derived or gene-modified vascular organoids can be employed to study disease development, progression and oncogenesis. C. Patientcompatible vascular organoids for application in regenerative medicine. $D$. Scalable, translatable vascular organoid-based platforms for high-throughput drug screening and development. 





(1)

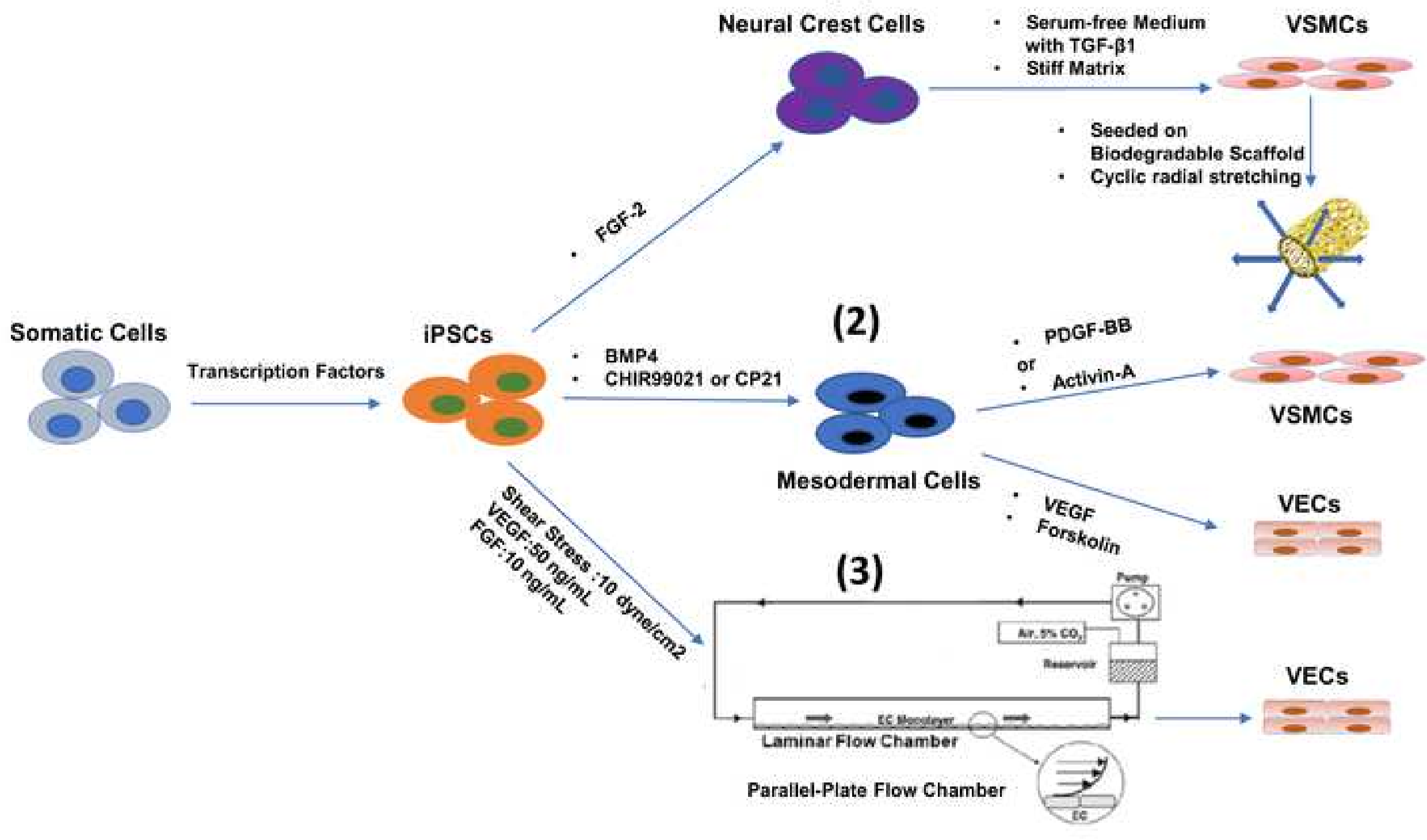

\section{Somatic Cells}

Transcription Factors

\section{(1)}

iPSCs 
A

\section{D hydrogel matrix}



B

Gene-editing via CaIspr-Cas9

B2 $\mathrm{m}^{-1-/ C i n t a r-/ C d 47}$ iPSCs via CRISPR.

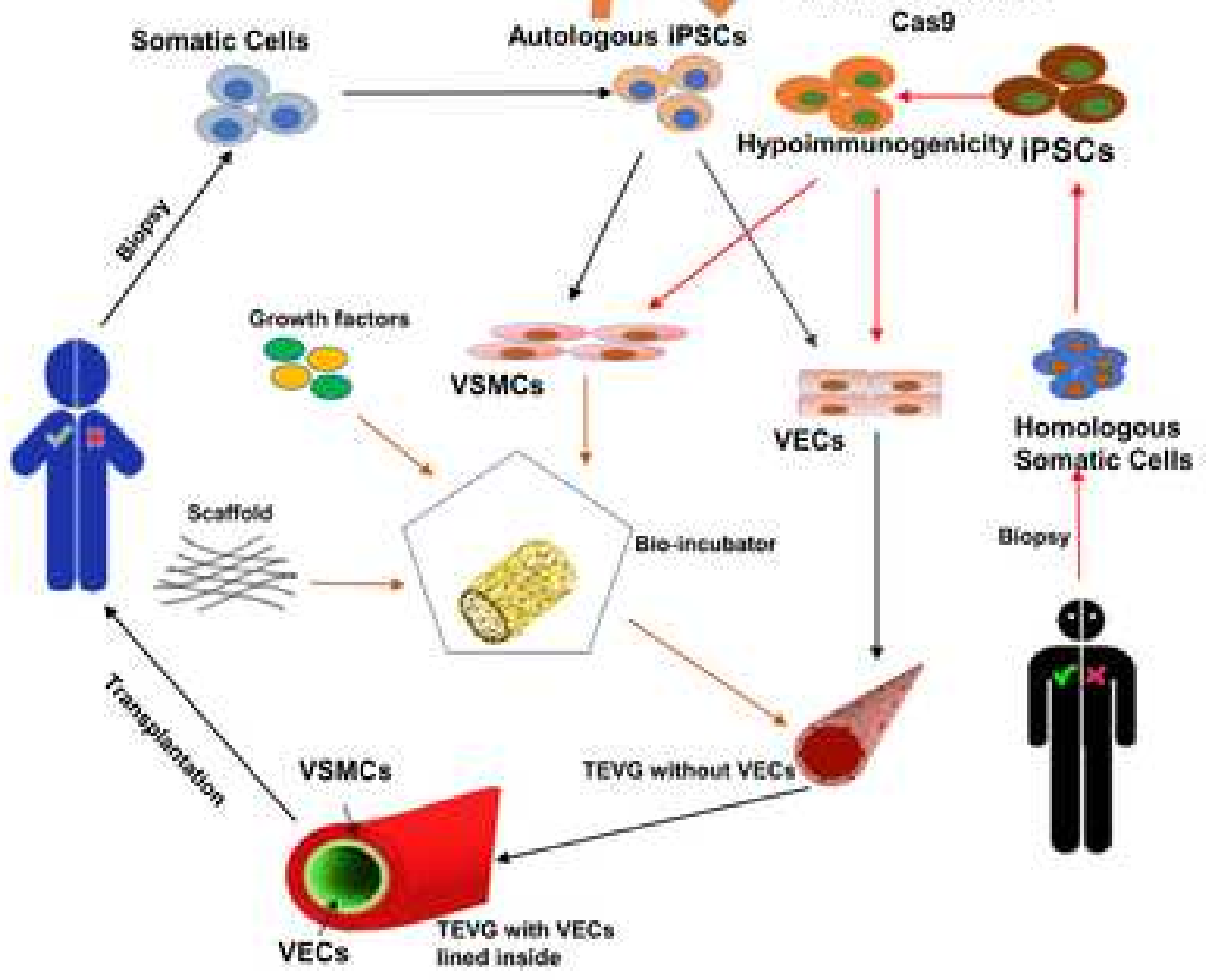




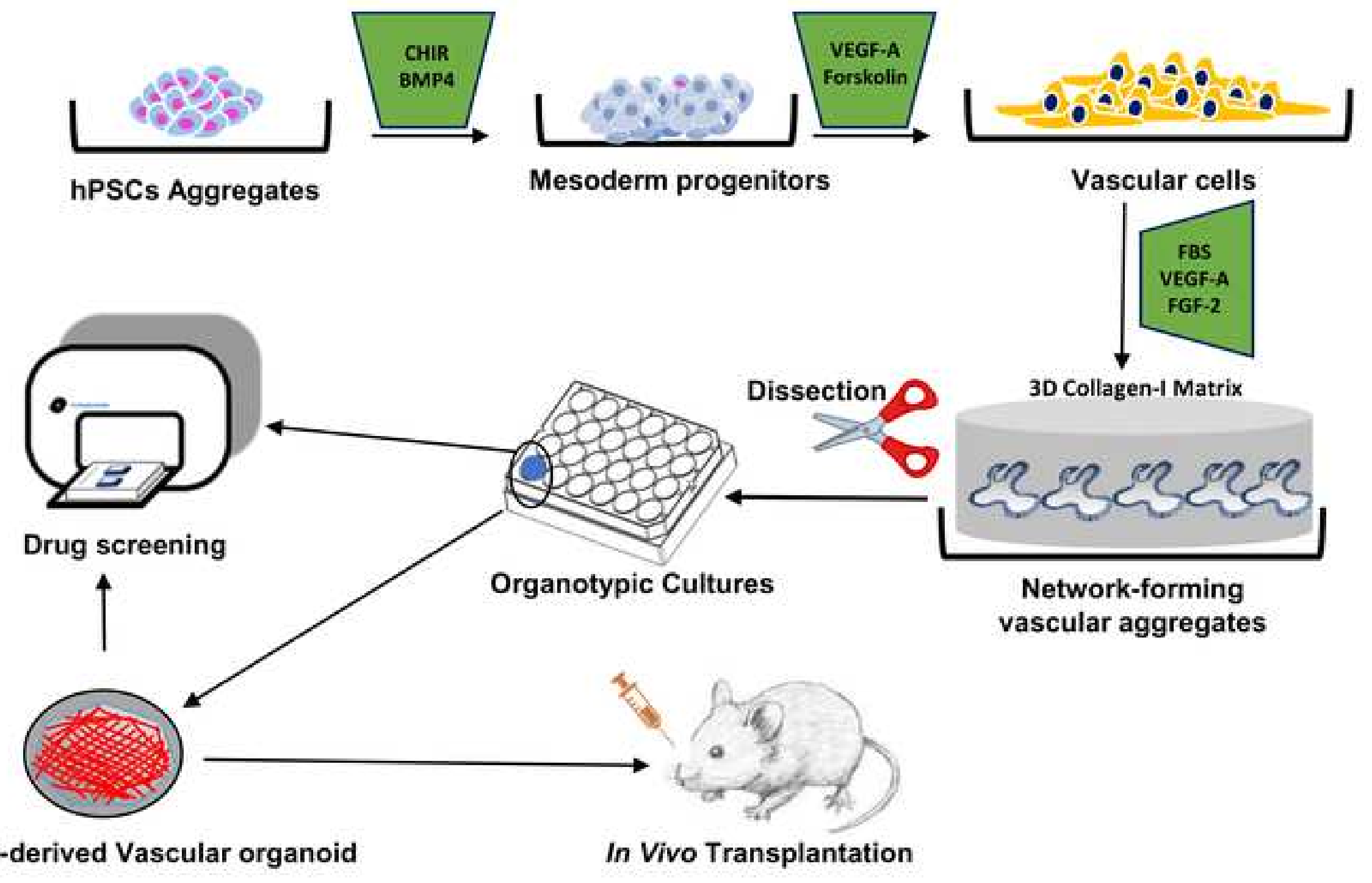

PSC-derived Vascular organoid

In Vivo Transplantation 

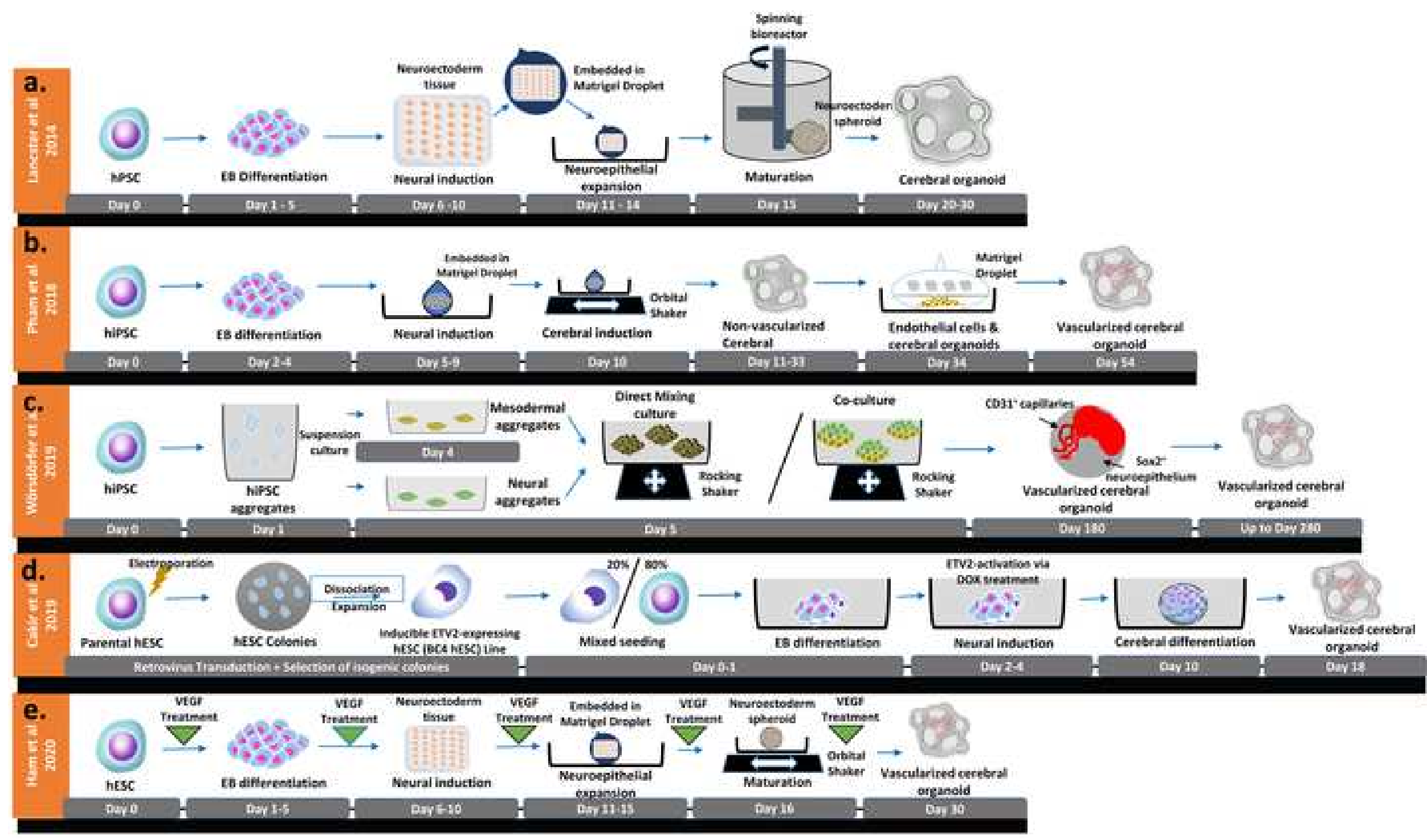


\section{A: Organ Development Model}

$2=$

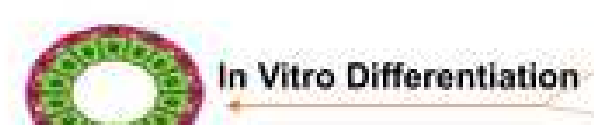

Transplantation

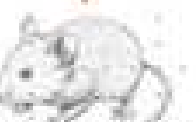

Maturation In Vivo

\section{C: Regeneration Model}
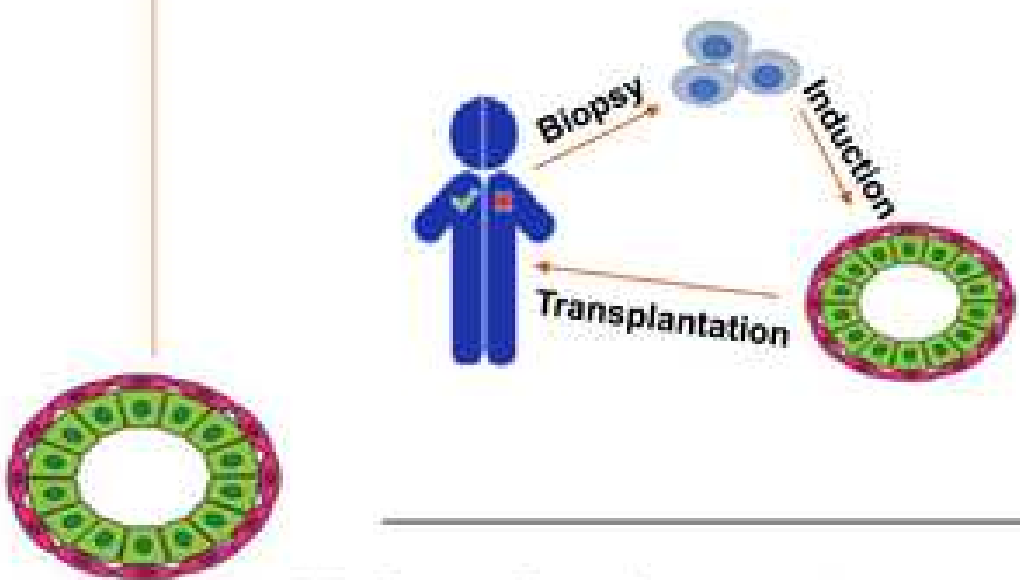

Organoid D: Drug Development

Hereditary Disease

Model

Tumour Model

Infection Model

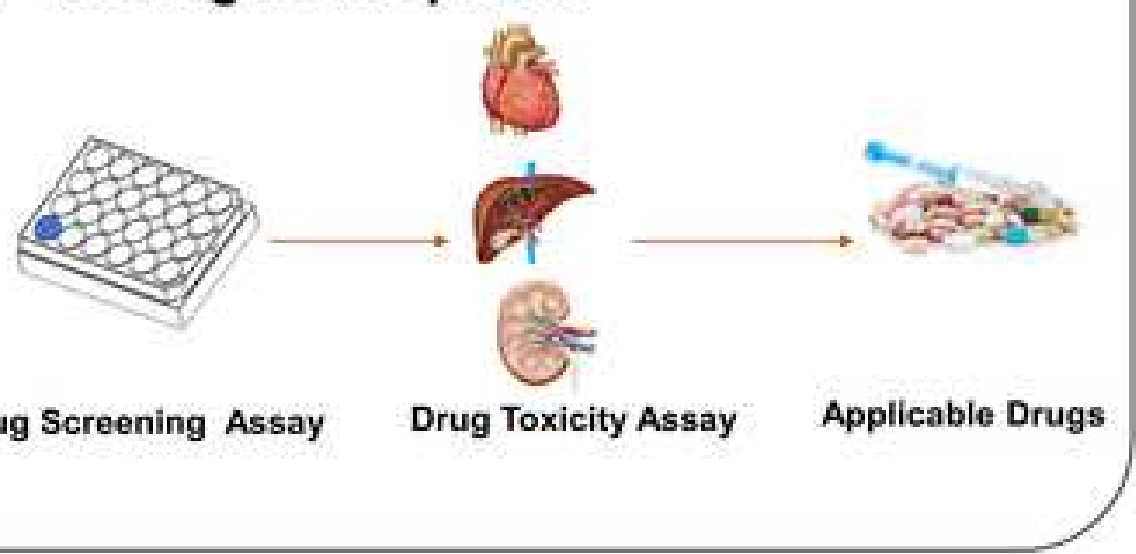




\section{Human vascular organoid generation \& applications}

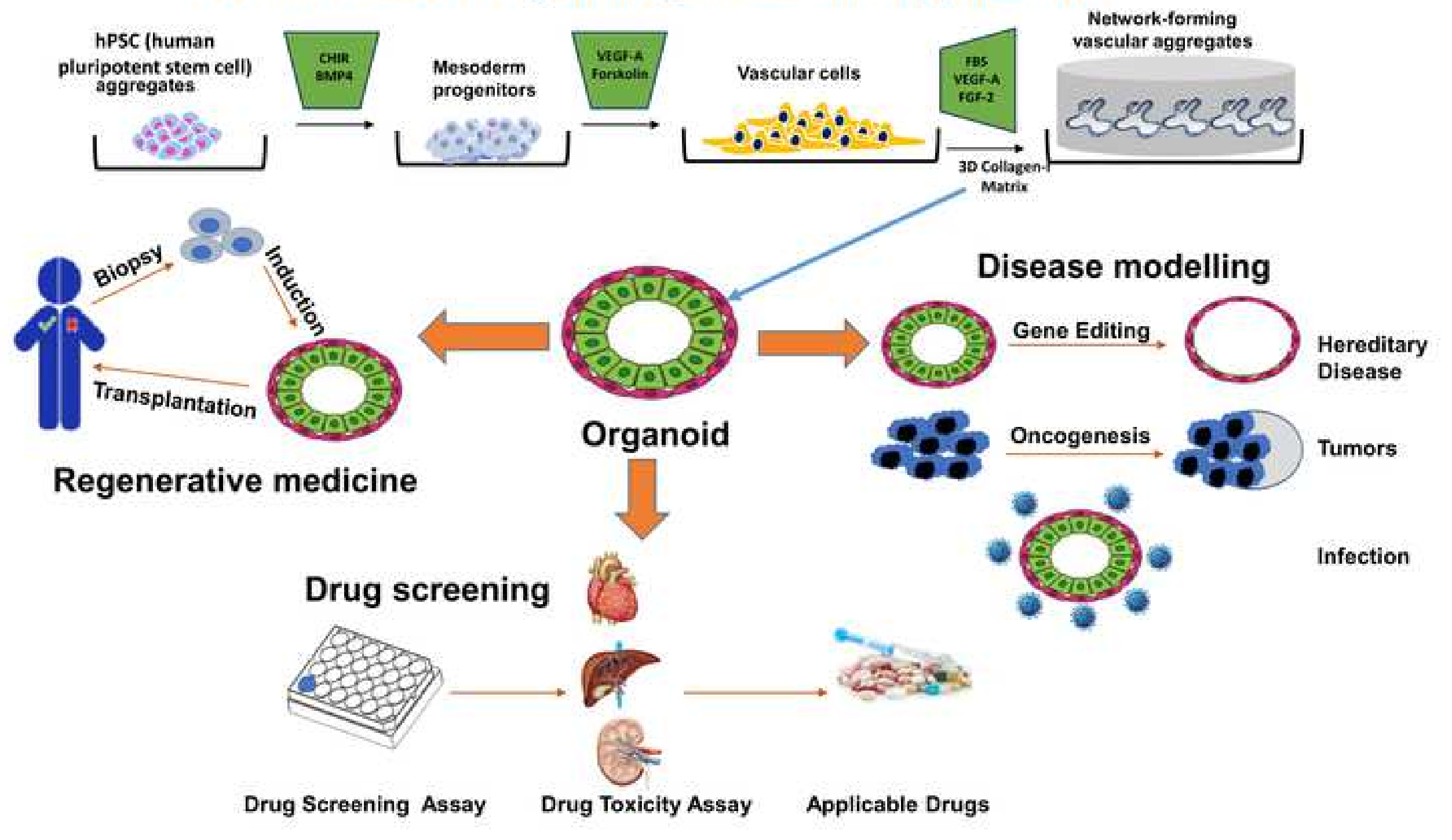

Drug Screening Assay Drug Toxicity Assay Applicable Drugs 